\title{
Structural and mechanistic insights into an extracytoplasmic copper trafficking pathway in Streptomyces lividans
}

\author{
Katie L. I. M. BLUNDELL*, Michael A. HOUGH*, Erik VIJGENBOOM† and Jonathan A. R. WORRALL*1 \\ ${ }^{*}$ School of Biological Sciences, University of Essex, Wivenhoe Park, Colchester CO4 3SQ, U.K. \\ $\dagger$ Molecular Biotechnology, Institute of Biology, Sylvius Laboratory, Leiden University, P0 Box 9505, 2300RA Leiden, The Netherlands
}

In Streptomyces lividans an extracytoplasmic copper-binding Sco protein plays a role in two unlinked processes: (i) initiating a morphological development switch and (ii) facilitating the cofactoring of the $\mathrm{Cu}_{\mathrm{A}}$ domain of $\mathrm{CcO}$ (cytochrome $c$ oxidase). How Sco obtains copper once secreted to the extracytoplasmic environment is unknown. In the present paper we report on a protein possessing an $\mathrm{HX}_{6} \mathrm{MX}_{21} \mathrm{HXM}$ motif that binds a single cuprous ion with subfemtomolar affinity. High-resolution X-ray structures of this extracytoplasmic copper chaperone-like protein $(\mathrm{ECuC})$ in the apo- and $\mathrm{Cu}(\mathrm{I})$-bound states reveal that the latter possesses a surface-accessible cuprous-ion-binding site located in a dish-shaped region of $\beta$-sheet structure. A cuprous ion is transferred under a favourable thermodynamic gradient from ECuC to Sco with no back transfer occurring. The ionization properties of the cysteine residues in the $\mathrm{Cys}^{86} \mathrm{xxxCys}^{90}$ copperbinding motif of Sco, together with their positional locations identified from an X-ray structure of Sco, suggests a role for $\mathrm{Cys}^{86}$ in initiating an inter-complex ligand-exchange reaction with $\mathrm{Cu}(\mathrm{I})-\mathrm{ECuC}$. Generation of the genetic knockouts, $\Delta$ sco, $\Delta e c u c$ and $\Delta$ scolecuc, and subsequent in vivo assays lend support to the existence of a branched extracytoplasmic copper-trafficking pathway in $S$. lividans. One branch requires both Sco and to a certain extent $\mathrm{ECuC}$ to cofactor the $\mathrm{Cu}_{\mathrm{A}}$ domain, whereas the other uses only Sco to deliver copper to a cuproenzyme to initiate morphological development.

Key words: copper chaperone, cytochrome $c$ oxidase, morphological development, Streptomyces.

\section{INTRODUCTION}

Copper $(\mathrm{Cu})$ is an essential transition metal ion in biology and is required for the function of many proteins and enzymes involved in processes requiring electron transfer, such as in photosynthesis and respiration, as well as in the catalytic oxidation of various substrates. The reversible $\mathrm{Cu}(\mathrm{I}) / \mathrm{Cu}$ (II) redox couple, crucial for biological function, also makes $\mathrm{Cu}$ toxic if not maintained in a tightly bound state in intracellular compartments due to $\mathrm{Cu}(\mathrm{I})$ being complicit in Fenton-like chemistry and by interfering in $[\mathrm{Fe}-\mathrm{S}]$ protein assembly [1]. To avoid such deleterious effects, $\mathrm{Cu}$-trafficking pathways in eukaryotic and prokaryotic organisms are operative. Central to these pathways are $\mathrm{Cu}$ metallochaperones delivering $\mathrm{Cu}$ to apo-forms of $\mathrm{Cu}$-requiring proteins and enzymes or to membrane transporters that act to efflux $\mathrm{Cu}$ across the cell membrane to maintain homoeostasis [2-4]. Insight into how $\mathrm{Cu}$ transfer is facilitated between proteins has been demonstrated through NMR solution studies [5-9]. The current understanding is that transient protein-protein interactions expedite metal-ligand exchange reactions without the dissociation of the metal to the bulk solvent, ensuring that the potentially toxic cargo always remains secure.

The biogenesis of the $\mathrm{Cu} / \mathrm{haem} a a_{3}$-type $\mathrm{CcO}$ (cytochrome $c$ oxidase) in aerobic organisms involves a Cu-trafficking pathway utilizing $\mathrm{Cu}$ metallochaperones [4]. $\mathrm{CcO}$ is an essential enzyme in aerobic respiration and is responsible for the reduction of molecular oxygen to water, utilizing two $\mathrm{Cu}$ centres in this reduction process: the dinuclear $\mathrm{Cu}_{\mathrm{A}}$ site in $\mathrm{CcO}$ subunit II and the $\mathrm{Cu}_{\mathrm{B}}$ site in $\mathrm{CcO}$ subunit I [10]. In eukaryotes, the $\mathrm{Cu}$ metallochaperone Cox 17 mediates $\mathrm{Cu}(\mathrm{I})$ transfer to the membrane-tethered Cox 11 and Scol proteins which reside in the inter-membrane space of mitochondria [11]. Cox11 is implicated in $\mathrm{Cu}_{\mathrm{B}}$ site assembly $[12,13]$ and $\mathrm{Sco} 1$ acts to metallate the dinuclear $\mathrm{Cu}_{\mathrm{A}}$ site [14-16]. In prokaryotes, the assembly of the $\mathrm{Cu}_{\mathrm{A}}$ site in $a a_{3}$-type $\mathrm{CcO}$ is less clear [17]. Cox 17 is not present in prokaryotic genomes, but Scolike proteins have been ubiquitously identified and characterized [17]. In certain bacteria, a gene has been identified which encodes for a membrane-attached protein with a $\mathrm{H}(\mathrm{M}) \mathrm{X}_{\mathrm{n}} \mathrm{MX}_{21 / 22} \mathrm{HXM}$ $\mathrm{Cu}$-binding motif (Figure 1) $[9,18,19]$. The genes encoding these proteins are often located directly up- or down-stream of a gene encoding a Sco-like protein, and a role as a $\mathrm{Cu}(\mathrm{I})$ metallochaperone, possibly in a similar manner to the eukaryotic Cox17, was initially inferred [18]. Subsequent in vitro experiments with $\mathrm{PCu}_{\mathrm{A}} \mathrm{C}$ (periplasmic $\mathrm{Cu}_{\mathrm{A}}$ chaperone) from Thermus thermophilus have revealed direct $\mathrm{Cu}(\mathrm{I})$ transfer to the $\mathrm{Cu}_{\mathrm{A}}$ site of $\mathrm{CcO}$ in the presence of apo-Sco [9]. This was interpreted as Sco acting as a thiol-disulfide reductase, maintaining the cysteine residues in the apo- $\mathrm{Cu}_{\mathrm{A}}$ site in a reduced form to facilitate $\mathrm{Cu}(\mathrm{I})$ delivery from $\mathrm{PCu}_{\mathrm{A}} \mathrm{C}$. Recent, in vivo studies in Rhodobacter sphaeroides cannot, however, reconcile $\mathrm{PCu}_{\mathrm{A}} \mathrm{C}$ with a significant role in directly metallating the $\mathrm{Cu}_{\mathrm{A}}$ site [20], nor incidentally for PcuC (a $\mathrm{PCu}_{\mathrm{A}} \mathrm{C}$ homologue) in Bradyrhizobium japonicum [19].

The genome sequence of the Gram-positive bacterium Streptomyces lividans 1326 has recently been determined [21]. This Streptomyces strain has a distinct dependence on $\mathrm{Cu}$ ions to stimulate morphological development and antibiotic production [22-26]. Recently, we have used a combination of in vivo and in vitro studies to present convincing evidence that a plasma membrane-tethered extracytoplasmic Sco protein in S. lividans (SLI4214; $\mathrm{Sco}^{\mathrm{Sl}}$ ) acts not as a thiol-disulfide reductase, but as a $\mathrm{Cu}$ (II)-metallochaperone, responsible under low $[\mathrm{Cu}]$ for the $a a_{3}$ type $\mathrm{CcO}$ activity and initiating a morphological development

Abbreviations: BCA, bicinchoninic acid; BCS, bathocuprione disulfonate; $\mathrm{CcO}$, cytochrome $c$ oxidase; ECuC, extracytoplasmic copper chaperone; $\mathrm{PCu}_{\mathrm{A}} \mathrm{C}$, periplasmic $\mathrm{Cu}_{\mathrm{A}}$ chaperone; SFM, soya flower mannitol; TMPD, $N, N, N^{\prime}, N^{\prime}$-tetramethyl-p-phenylenediamine; WT, wild-type.

1 To whom correspondence should be addressed (email jworrall@essex.ac.uk). 


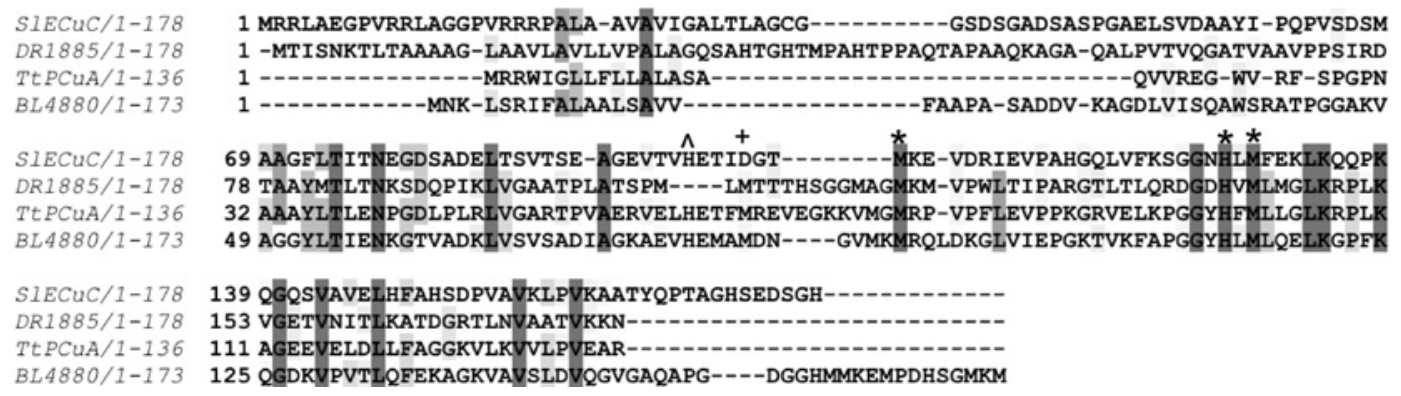

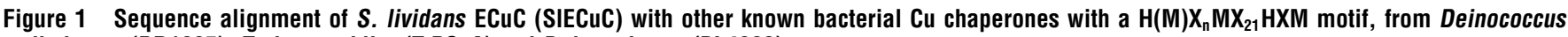
radiodurans (DR1885), T. thermophilus (TtPCuA) and B. japonicusm (BL4880)

Completely and partially conserved residues are boxed from dark to light respectively. The $\mathrm{MX}_{21} \mathrm{HXM}$ part of the motif, conserved across each species, is indicated with a *, with the first residue in the motif, a histidine for ECuC, TtPCuA and BL4880 $\left({ }^{\wedge}\right)$, and a methionine $(+)$ for DR1885.

switch in the life cycle, two unlinked functions [26]. The two genes immediately downstream of the sco gene reveal features that suggest involvement in $\mathrm{Cu}$ handling and trafficking, with SLI4213 having a $\mathrm{HX}_{6} \mathrm{MX}_{21} \mathrm{HXM}$ motif (Figure 1) and the SLI4212 gene, encoding a putative integral membrane transporter with Cu-binding CopC-and CopD-like domains [27]. This operon structure suggests that a source of $\mathrm{Cu}(\mathrm{I})$ for SLI4213 in the extracytoplasmic environment is via SLI4212, which could then be trafficked to enzymes or other chaperones as required. In some Gram-positive bacteria, e.g. Bacillus subtilis, no gene encoding a protein with a $\mathrm{H}(\mathrm{M}) \mathrm{X}_{\mathrm{n}} \mathrm{MX}_{21 / 22} \mathrm{HXM}$ has been identified, and the metallation of the $\mathrm{Cu}_{\mathrm{A}}$ site of $\mathrm{CcO}$ is inferred to be facilitated by a $\mathrm{Cu}(\mathrm{II})-\mathrm{Sco}$ interaction [28,29]. In S. lividans and other streptomycetes the role and functional relationship with Sco and/or $\mathrm{CcO}$ of an extracytoplasmic $\mathrm{PCu}_{\mathrm{A}} \mathrm{C}$-like protein has yet to be explored. To extend on our previous studies where we have shown that $\mathrm{Sco}^{\mathrm{Sl}}$ functions to (i) metallate the $\mathrm{Cu}_{\mathrm{A}}$ site of $\mathrm{CcO}$, and (ii) initiate a development switch [26], in the present study we specifically address whether an extracytoplasmic $\mathrm{Cu}$ trafficking pathway exists between $\mathrm{Sco}^{\mathrm{Sl}}$ and the SLI4213 gene product. On the basis of its extracytoplasmic location and our $\mathrm{Cu}$-binding studies reported herein, we refer to the SLI4213 protein as $\mathrm{ECuC}$ (extracytoplasmic copper chaperone). Using a combination of structural and biochemical studies we show that $\mathrm{Cu}(\mathrm{I})$ is transferred in a unidirectional manner from $\mathrm{ECuC}$ to $\mathrm{Sco}^{\mathrm{Sl}}$. Our analysis suggests that a transient electrostatic complex is formed, with $\mathrm{Cu}(\mathrm{I})$ transfer proceeding via a ligandexchange mechanism with $\mathrm{Cys}^{86}$, part of the $\mathrm{Cys}^{86} \mathrm{xxxCys}^{90} \mathrm{Cu}$ binding motif in $\mathrm{Sco}^{\mathrm{Sl}}$, having an important role. In vivo studies using genetic knockouts reveal that under low exogenous $\mathrm{Cu}$ concentrations, morphological development is independent of $\mathrm{ECuC}$, but $\mathrm{CcO}$ activity is decreased relative to the WT (wildtype) S. lividans 1326 strain, implying a co-ordinated role as a $\mathrm{Cu}$ donor to $\mathrm{Sco}^{\mathrm{Sl}}$ in maturation of the $\mathrm{Cu}_{\mathrm{A}}$ site in $\mathrm{CcO}$.

\section{MATERIALS AND METHODS}

\section{Cloning and overexpression of ECuC in Escherichia coli}

Bioinformatic analysis predicted the gene product of SLI4213 to contain an N-terminal TAT pathway signal peptide (http://www. compgen.org/tools/PRED-TAT), and an SPII cleavage site and lipobox (LAGC) just upstream of $\mathrm{Cys}^{37}$, thus suggesting that the SLI4213 product is a lipoprotein (http://www.cbs.dtu.dk/services/ LipoP/, http://bioinformatics.biol.uoa.gr/PRED-LIPO, http:// signalfind.org/tatlipo.html). To facilitate the overexpression and to ensure enhanced solubility of the purified product, an N-terminaltruncated SLI4213 gene encoding amino acid residues 42-178 of ECuC was amplified from S. lividans 1326 genomic DNA (S. lividans 66, stock-number 1326, John Innes Collection) and ligated into the NdeI and HindIII restriction sites of a pET28a vector (Novagen) to create an $\mathrm{N}$-terminal $\mathrm{His}_{6}$-tagged construct for overexpression in E. coli. ECuC was overexpressed in $E$. coli strain BL21(DE3) cells starting from overnight pre-cultures [ $2 \mathrm{ml}$ of $2 \times \mathrm{YT}$ and $2 \mu \mathrm{l}$ of kanamycin $(50 \mathrm{mg} / \mathrm{ml}), 37^{\circ} \mathrm{C}$ ] that were subsequently used to inoculate $750 \mathrm{ml}$ of medium in 2 litre flasks. At a $D_{600}$ of 0.6 , IPTG (Melford) was added to a final concentration of $1 \mathrm{mM}$ and the temperature was decreased to $25^{\circ} \mathrm{C}$. Cells were harvested after $16 \mathrm{~h}$ at $3860 \mathrm{~g}$ and lysed using an EmulsiFlex-C5 cell disrupter (Avestin) followed by centrifugation at $38724 \mathrm{~g}$ for $20 \mathrm{~min}$ at $4{ }^{\circ} \mathrm{C}$. The clarified supernatant was loaded on to a $5 \mathrm{ml} \mathrm{Ni-NTA}\left(\mathrm{Ni}^{2+}\right.$-nitrilotriacetate) Sepharose column (GE Healthcare) equilibrated with Buffer A $[50 \mathrm{mM}$ Tris/ $\mathrm{HCl}$, $500 \mathrm{mM} \mathrm{NaCl}$ and $20 \mathrm{mM}$ imidazole (pH 8.0)] and eluted with a linear imidazole gradient using Buffer B (Buffer A with $500 \mathrm{mM}$ imidazole). A single peak at $\sim 22 \%$ Buffer B was eluted from the column and fractions were pooled and dialysed overnight at $4{ }^{\circ} \mathrm{C}$ against Buffer $\mathrm{C}[50 \mathrm{mM}$ Tris/ $\mathrm{HCl}, 150 \mathrm{mM} \mathrm{NaCl}$ and $1 \mathrm{mM}$ EDTA (pH 8.0)]. Concentrated protein was loaded on to a G75 Sephadex column (GE Healthcare) equilibrated with Buffer C. Fractions eluting in the major peak of the G75 column were analysed by SDS/PAGE ( $15 \%$ gel) and those deemed of good purity were concentrated and stored at $-20^{\circ} \mathrm{C}$ until required. ESI-MS using a Micromass Quattro Ultima triple quadrupole instrument operating in the positive-ion detection mode was used to determine the mass of the purified samples, with individual proteins first desalted and exchanged into $1 \mathrm{M}$ ammonium acetate followed by a 1:20 dilution with a $50 \%$ methanol and $1 \%$ formic acid solution.

\section{Overexpression and purification of $\mathrm{Sco}^{\mathrm{SI}}$}

The overexpression of the N-terminal-truncated WT Sco ${ }^{\mathrm{Sl}}$ and the C86A, C90A and H176A mutants were carried out as described previously $[26,30]$. The purified proteins consist of residues 24 216.

\section{Generation of the $\Delta$ ecuc and $\Delta$ sco/ecuc mutants of $S$. lividans 1326}

The agar media SFM (soya flower mannitol), R5 (complex medium) and Difco nutrient agar were prepared according to 
Kieser et al. [31]. Antibiotics were used in the following final concentrations: $50 \mu \mathrm{g} / \mu \mathrm{l}$ apramycin and 5-20 $\mu \mathrm{g} / \mu \mathrm{l}$ thiostrepton. Agar plates were incubated at $30^{\circ} \mathrm{C}$ and spore stocks were obtained from cultures grown on SFM plates and stored in $20 \%$ glycerol at $-20^{\circ} \mathrm{C}$. The $\mathrm{ECuC}$ mutant $(\Delta e c u c)$ and the double mutant lacking both $\mathrm{ECuC}$ and $\mathrm{Sco}(\Delta$ scolecuc) were isolated essentially according to the protocol described previously [26]. In the $\Delta e c u c$ mutant, nucleotides +21 to +500 of the SLI4213 ORF were replaced by a 62-nt scar of the lox recombination site including two $\mathrm{XbaI}$ sites. In the double mutant $\Delta$ sco/ecuc, SLI4214 from nucleotide +33 and SLI4213 up to nucleotide +500 were replaced by the Lox-scar. Both mutants were analysed by PCR to confirm the loss of the gene(s).

\section{In vivo $\mathrm{CcO}$ assay}

The in vivo $\mathrm{CcO}$ activity was visualized with TMPD $\left(N, N, N^{\prime}, N^{\prime}-\right.$ tetramethyl- $p$-phenylenediamine) as a substrate essentially as described previously $[26,32,33]$. Each strain was spotted on Difco nutrient agar plates (10 $\mu$ l containing 1000 spores $)$ and incubated for $24-30 \mathrm{~h}$ at $30^{\circ} \mathrm{C}$. Mycelium spots were fixed with a light spray of $0.3 \%$ agarose in water and overlaid with $10 \mathrm{ml}$ of a $25 \mathrm{mM}$ phosphate buffer ( $\mathrm{pH} 7.4)$ solution containing $20 \%$ ethanol, $0.6 \%$ agarose, $1 \%$ sodium deoxycholate and $10 \mathrm{mg}$ of TMPD. CcO activity was recorded by taking digital images every $30 \mathrm{~s}$ for 5-10 min. The ImageJ software (NIH) was used to calculate average pixel intensities of the Indophenol Blue-stained mycelium. After correction for background reading, the data were multiplied by -1 and plotted as arbitrary units against time.

\section{UV-visible and CD spectroscopies}

Concentrations of all apo-proteins were determined by UVvisible spectroscopy (Varian Cary 50 UV-visible spectrophotometer) using molar absorption coefficients $(\varepsilon)$ at $280 \mathrm{~nm}$ of $2980 \mathrm{M}^{-1} \cdot \mathrm{cm}^{-1}$ for $\mathrm{ECuC}, 14565 \mathrm{M}^{-1} \cdot \mathrm{cm}^{-1}$ for $\mathrm{Sco}^{\mathrm{Sl}}$ and the H176A mutant, and $14440 \mathrm{M}^{-1} \cdot \mathrm{cm}^{-1}$ for the C86A and C90A mutants of $\mathrm{Sco}^{\mathrm{Sl}}$ [34]. Protein samples $(20 \mu \mathrm{M})$ for $\mathrm{CD}$ analysis were exchanged into $10 \mathrm{mM}$ potassium phosphate and $50 \mathrm{mM}$ potassium fluoride and far UV-CD spectra were recorded between 260 and $175 \mathrm{~nm}$ at $20^{\circ} \mathrm{C}$ on an Applied Photophysics Chirascan CD spectrophotometer equipped with a thermostatic cell holder. CD spectra were analysed using DichroWeb [35].

\section{Competition assays to determine $\mathrm{Cu}(\mathrm{I})$-binding affinities}

$\mathrm{CuCl}$ (Sigma) was dissolved under anaerobic conditions (DWScientific anaerobic chamber) in $10 \mathrm{mM} \mathrm{HCl}$ and $500 \mathrm{mM} \mathrm{NaCl}$. The $\mathrm{Cu}(\mathrm{I})$ concentration was determined spectrophotometrically by step-wise addition to a known concentration of the $\mathrm{Cu}(\mathrm{I})$ specific bidentate chelator BCA (bicinchoninic acid) using an $\varepsilon$ at $562 \mathrm{~nm}$ of $7900 \mathrm{M}^{-1} \cdot \mathrm{cm}^{-1}$ for $\left[\mathrm{Cu}(\mathrm{BCA})_{2}\right]^{3-}$. Protein samples were prepared anaerobically in $10 \mathrm{mM}$ Mops $(\mathrm{pH} 7.5)$ and $200 \mathrm{mM} \mathrm{NaCl}$, and, in the case of WT and the H176A mutant of $\mathrm{Sco}^{\mathrm{Sl}}$, cysteine residues were reduced by overnight incubation in the presence of $5 \mathrm{mM}$ DTT followed by desalting using a PD-10 column (GE Healthcare). Competition assays were set up anaerobically with either BCA or BCS (bathocuprione disulfonate) (Sigma). Increasing protein concentrations (0$50 \mu \mathrm{M})$ were added to solutions of $\left[\mathrm{Cu}^{\mathrm{I}} \mathrm{L}_{2}\right]^{3-}$ of defined molar ratio $\mathrm{L}: \mathrm{Cu}(\mathrm{I}) \geqslant 3$, creating a series of individual solutions with constant $\left[\mathrm{Cu}^{\mathrm{I}}\right]$ and $[\mathrm{L}]$ and various [protein]. Samples were left for $\sim 1 \mathrm{~h}$ and the transfer of $\mathrm{Cu}(\mathrm{I})$ from the $\left[\mathrm{Cu}^{\mathrm{I}} \mathrm{L}_{2}\right]^{3-}$ complex to the protein was determined by measuring the absorbance of the $\left[\mathrm{Cu}^{\mathrm{I}} \mathrm{L}_{2}\right]^{3-}$ complex spectrophotometrically for $\mathrm{L}=\mathrm{BCA}$ at $562 \mathrm{~nm}\left(\varepsilon=7900 \mathrm{M}^{-1} \cdot \mathrm{cm}^{-1}\right)$ [36] and $\mathrm{L}=\mathrm{BCS}$ at $483 \mathrm{~nm}\left(\varepsilon=13000 \mathrm{M}^{-1} \cdot \mathrm{cm}^{-1}\right)$ [37]. By interchanging L, assays favouring competitive or non-competitive $\mathrm{Cu}(\mathrm{I})$ binding could be set-up, which for the latter led to an estimate of the binding stoichiometry. The dissociation constant for $\mathrm{Cu}(\mathrm{I})\left[K_{\mathrm{d}}\left(\mathrm{Cu}^{\mathrm{I}}\right)\right]$ was determined from competitive assays by assuming the following reaction (eqn 1):

apo $-\mathrm{P}+\mathrm{CuL}_{2} \leftrightarrow \mathrm{Cu}(\mathrm{I})-\mathrm{P}+2 \mathrm{~L}$

where $\mathrm{P}$ is protein, and by using eqn (2):

$K_{\mathrm{d}} \beta_{2}=\frac{\left([\text { apo }-\mathrm{P}]_{\text {tot }} /[\mathrm{M}-\mathrm{P}]\right)-1}{\left\{\left([\mathrm{~L}]_{2} /\left[\mathrm{ML}_{2}\right]\right)-2\right\}\left[\mathrm{ML}_{2}\right]}$

where [L] is the total ligand concentration (BCA or BCS) and the overall formation constant $\left(\beta_{2}\right)$ is $10^{17.2} \mathrm{M}^{-2}$ for $\left[\mathrm{Cu}(\mathrm{BCA})_{2}\right]^{3-}$ and $10^{19.8} \mathrm{M}^{-2}$ for $\left[\mathrm{Cu}(\mathrm{BCS})_{2}\right]^{3-}[36,38]$. Assays were performed in triplicate and the $K_{\mathrm{d}}\left(\mathrm{Cu}^{\mathrm{I}}\right)$ value for a series was initially calculated for each individual solution and then averaged.

\section{Fluorescence spectroscopy}

Fluorescence spectroscopy was carried out on a LS 50B fluorimeter (PerkinElmer), thermostatically controlled at $20^{\circ} \mathrm{C}$. Tryptophan fluorescence emission spectra of $\mathrm{WT} \mathrm{Sco}^{\mathrm{Sl}}$ and mutants were collected between 300 and $400 \mathrm{~nm}$ following excitation at $295 \mathrm{~nm}$. The excitation slit and the emission slit were set at $5 \mathrm{~nm}$.

\section{Determining the $\mathrm{p} K_{\mathrm{a}}$ values of cysteine residues}

Reduced apo-proteins $(\sim 300 \mu \mathrm{M})$ were prepared in an anaerobic chamber in $5 \mathrm{mM}$ Mops (pH 7.5) and $25 \mathrm{mM} \mathrm{KCl}$, together with a series of mixed buffer systems containing $10 \mathrm{mM}$ each of potassium acetate, Mes, Mops and Tris, and $200 \mathrm{mM} \mathrm{NaCl}$, with the $\mathrm{pH}$ of each solution individually adjusted in increments of 0.5 from $\mathrm{pH}$ values of 3-10. Reduced protein was added to each buffered solution to give a final concentration of $30 \mu \mathrm{M}$ and the $\varepsilon$ at $240 \mathrm{~nm}\left(\varepsilon_{240}\right)$ was determined spectrophotometrically in a sealed quartz cuvette and plotted as a function of $\mathrm{pH}$. Models describing one (eqn 3 ) or two (eqn 4) non-interacting macroscopic ionizations were used to determine $\mathrm{p} K_{\mathrm{a}}$ values of the cysteine residues $\left(\mathrm{p} K_{\text {Cys }}\right)$ :

$\varepsilon_{240}=\varepsilon_{0}+\frac{\Delta \varepsilon 10^{\mathrm{pH}-\mathrm{p} K_{\mathrm{a}}}}{1+10^{\mathrm{pH}-\mathrm{p} K_{\mathrm{a}}}}$
$\varepsilon_{240}=\varepsilon_{0}+\frac{\Delta \varepsilon 10^{\mathrm{pH}-\mathrm{p} K_{\mathrm{a} 1}}+\Delta \varepsilon_{2} 10^{2 \mathrm{pH}-\mathrm{p} K_{\mathrm{a} 1}-\mathrm{p} K_{\mathrm{a} 2}}}{1+10^{\mathrm{pH}-\mathrm{p} K_{\mathrm{a} 1}}+10^{2 \mathrm{pH}-\mathrm{p} K_{\mathrm{a} 1}-\mathrm{p} K_{\mathrm{a} 2}}}$

where $\varepsilon_{\mathrm{o}}$ is the extinction of the thiol form and $\Delta \varepsilon$ is the difference between the molar absorption coefficient of a thiol and thiolate form. The $\mathrm{p} K_{\mathrm{a}}$ values reported are an average of multiple datasets and the error reported is the S.D.

\section{Crystallization and structure determinations}

Crystals of $\mathrm{Cu}(\mathrm{I})-\mathrm{ECuC}$, apo-ECuC and Sco C90A were grown using the hanging-drop vapour diffusion method at $20^{\circ} \mathrm{C}$. Equal volumes of protein solution at a concentration of $15-20 \mathrm{mg} / \mathrm{ml}$ were mixed with an equal volume of reservoir solution containing $30 \%$ PEG-MME 2000 and $0.1 \mathrm{M}$ potassium thiocyanate for 
Table 1 Crystallographic data collection and processing statistics for S. lividans ECuC and Sco C90A structures

Values in parentheses refer to the outermost resolution shells.

\begin{tabular}{|c|c|c|c|c|}
\hline Dataset & Cu(I)-ECuC (SAD) & Cu(I)-ECuC (high-resolution) & Apo-ECuC & Apo-Scosl C90A \\
\hline Wavelength $(\AA)$ & 0.9163 & 0.9163 & 1.20 & 0.98 \\
\hline Resolution $(\AA)$ & $34.6-2.30$ & $27.3-1.48$ & $34.1-1.70$ & $35.7-1.40$ \\
\hline Space group & $P 2{ }_{1}{ }_{1}{ }_{2}$ & $P 2_{1} 2_{1} 2_{1}$ & $P 2{ }_{1}{ }_{1} 2_{1}$ & $\mathrm{P}_{2}$ \\
\hline Unit cell $(\AA)$ & $44.4,47.9,50.1$ & $44.5,47.8,50.0$ & $43.6,47.7,49.0$ & $41.2,41.2,76.6$ \\
\hline Unique reflections & 5047 & 17951 & 44652 & 28622 \\
\hline Completeness (\%) & $99.3(99.5)$ & $98.1(98.8)$ & $98.0(89.5)$ & $99.8(98.5)$ \\
\hline$R_{\text {merge }}$ & $0.045(0.068)$ & $0.056(0.482)$ & $0.087(0.445)$ & $0.067(0.66)$ \\
\hline $\mathrm{Mn}(\mathrm{l} / \mathrm{sd})$ & $53.4(39.2)$ & $9.5(2.2)$ & $8.8(1.9)$ & $10.1(2.1)$ \\
\hline Redundancy & $20.6(23.1)$ & $3.3(3.4)$ & $3.9(2.4)$ & $3.3(2.4)$ \\
\hline Anomalous redundancy & $11.2(12.2)$ & - & - & - \\
\hline$R_{\text {cryst }}$ & - & 0.185 & 0.183 & 0.131 \\
\hline$R_{\text {free }}$ & - & 0.227 & 0.233 & 0.185 \\
\hline ESU based on $M L(\AA)$ & - & 0.057 & 0.080 & 0.044 \\
\hline \multicolumn{5}{|l|}{ RMSD } \\
\hline Bond lengths $(\AA)$ & - & 0.016 & 0.015 & 0.017 \\
\hline Bond angles $\left({ }^{\circ}\right)$ & - & 1.8 & 1.8 & 1.9 \\
\hline Ramachandran favoured (\%) & - & 95.0 & 95.2 & 98.1 \\
\hline Wilson $B$-factor $\left(\AA^{2}\right)$ & 23.5 & 26.6 & 29.3 & 17.6 \\
\hline PDB accession number & - & 3ZJA & $3 Z K O$ & 4BPY \\
\hline
\end{tabular}

$\mathrm{Cu}(\mathrm{I})-\mathrm{ECuC}, 31 \%$ PEG 8000, $0.1 \mathrm{M}$ sodium cacodylate ( $\mathrm{pH}$ 6.5) and $0.2 \mathrm{M}$ sodium acetate for apo-ECuC, and $28 \%$ PEG 4000 and $0.05 \mathrm{M}$ sodium acetate ( $\mathrm{pH} 4.5$ ) for Sco C90A. Crystals suitable for diffraction studies grew within 14 days. A single crystal was transferred to a cryoprotectant solution containing the respective reservoir solution and 10-20\% glycerol before flash-cooling by plunging into liquid nitrogen. Crystallographic data were measured at beamlines I04-1 [Cu(I)-ECuC], I02 (apo-ECuC) and I24 (Sco C90A) of the Diamond Light Source, using Xray wavelengths of $0.9163,1.20$ and $0.98 \AA(1 \AA=0.1 \mathrm{~nm})$ respectively and a Pilatus $6 \mathrm{M}$ detector (Dectris). Data were indexed using iMosflm [39] before scaling and merging using Scala [40] in the CCP4i suite. The structure of $\mathrm{Cu}(\mathrm{I})-\mathrm{ECuC}$ was solved by $\mathrm{Cu}-\mathrm{SAD}$ phasing in PHENIX [41] using the single intrinsic $\mathrm{Cu}$ atom. A high redundancy dataset (anomalous multiplicity of 11.2), measured to $2.3 \AA$ resolution was used to locate the $\mathrm{Cu}$ atom and, following density modification, to produce an electron-density map into which a partial model could be built. Extension of the resulting phases to a $1.48 \AA$ resolution dataset resulted in a clear electron-density map from which automatic model building using Buccaneer [42] and ARP/wARP [43] was successful in building 110 residues of the protein sequence. At this stage, the $\mathrm{Cu}$ ion was built into a $16 \sigma$ peak in the $F_{\mathrm{o}}-F_{\mathrm{c}}$ difference map. Subsequent refinement of the structure was carried out using Refmac5 [44] in the CCP4i suite, with model building between refinement cycles in Coot [45], extending the model to include residues 50-164. Riding hydrogen atoms were added when refinement of the protein atoms had converged and individual anisotropic $B$-factors were refined. The structure of apo-ECuC, to a $1.70 \AA$ resolution, was refined using the $\mathrm{Cu}(\mathrm{I})-$ $\mathrm{ECuC}$ structure, from which the $\mathrm{Cu}$ atom had been removed, as a starting model and refined in a similar way except that isotropic $B$-factors were used. Both structures were verified using the Molprobity server [46] and Coot [45]. The Sco C90A structure was solved by molecular replacement using the BALBES server [47] with a search model based on PDB entry $2 \mathrm{~B} 7 \mathrm{~K}$ producing a solution. Model building was initially carried out in ARP/wARP [43] and subsequent refinement and validation as described above. Co-ordinates and structure factors were deposited in the RCSB PDB with accession numbers 3ZJA ,3ZK0 and 4BPY for $\mathrm{Cu}(\mathrm{I})-$
ECuC, apo-ECuC and Sco C90A respectively A summary of data and refinement statistics and the quality indicators for all structures reported are given in Table 1.

\section{RESULTS}

\section{$\mathrm{Cu}(\mathrm{I})$ binding to apo-ECuC causes a large spectral transition in the CD spectrum}

From size-exclusion chromatography, ECuC (residues 42-178) eluted at a retention volume consistent with it being a monomer in solution, with a mass determined from ESI-MS of $14694 \pm 0.3$ $\mathrm{Da}$ (predicted $14694 \mathrm{Da}$ after $\mathrm{His}_{6}$ tag removal). In the UV-visible spectrum no absorption bands in the visible region were present, and only an absorption band in the UV region with a $\lambda_{\max }$ of $275 \mathrm{~nm}$, arising from the presence of a single tyrosine residue in the sequence, was observed. The far-UV CD spectrum reveals a shoulder at $\sim 230 \mathrm{~nm}$ that leads to a trough at $\sim 200 \mathrm{~nm}$ (Figure 2), which is not characteristic of a protein with either $\alpha$-helical or model $\beta$-sheet features, but is instead reminiscent of a spectrum reporting the presence of $\beta_{\mathrm{II}}$-type sheets. This secondary structure type has been suggested to consist of smaller $\beta$-strands that are not ordered or are distorted to one another [48]. Under anaerobic conditions the addition of $\mathrm{Cu}(\mathrm{I})$ to ECuC led to significant change in the far-UV CD spectrum that resulted in a positive peak at $200 \mathrm{~nm}$ and a trough at $\sim 235 \mathrm{~nm}$ (Figure 2). These features are now indicative of secondary structure dominated by model $\beta$-sheet implying that, in solution, $\mathrm{ECuC}$ binds $\mathrm{Cu}(\mathrm{I})$ causing reorganization of the sheet structure.

\section{$\mathrm{Cu}(\mathrm{I})$ binds to $S$. lividans ECuC with subfemtomolar affinity}

To explore further the $\mathrm{Cu}(\mathrm{I})$-binding properties of $\mathrm{ECuC}$, the $\mathrm{Cu}(\mathrm{I})$-specific chromogenic bidentate probes BCA and BCS were used under anaerobic conditions. Under the conditions used, addition of increasing amounts of ECuC into $\left[\mathrm{Cu}^{\mathrm{I}}(\mathrm{BCA})_{2}\right]^{3-}$ led to a decrease in the absorbance maximum at $562 \mathrm{~nm}$ of the $\left[\mathrm{Cu}^{\mathrm{I}}(\mathrm{BCA})_{2}\right]^{3-}$ complex (inset of Figure $3 \mathrm{~A}$ ), which when plotted against $[\mathrm{ECuC}] /[\mathrm{Cu}(\mathrm{I})]$ revealed that $\sim 1$ equivalent of 


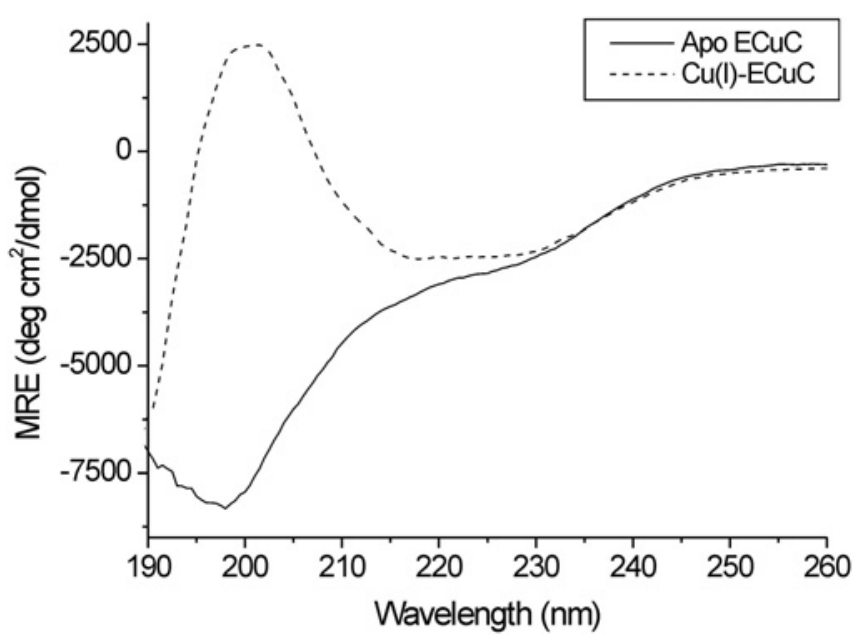

Figure 2 The far-UV CD spectra of $S$. lividans ECuC in the absence and presence of $\mathrm{Cu}(\mathrm{I})$

The apo-protein was incubated under anaerobic conditions with a stoichiometric addition of $\mathrm{Cu}(\mathrm{l})$ before measurement at $20^{\circ} \mathrm{C}$. Protein concentration was $20 \mu \mathrm{M}$ in $10 \mathrm{mM}$ potassium phosphate and $50 \mathrm{mM}$ potassium fluoride ( $\mathrm{pH} 7.5$ ).

$\mathrm{Cu}(\mathrm{I})$ is extracted from the $\left[\mathrm{Cu}^{\mathrm{I}}(\mathrm{BCA})_{2}\right]^{3-}$ complex per monomer of $\mathrm{ECuC}$ (Figure 3A). This implies that $\mathrm{ECuC}$ binds $\mathrm{Cu}(\mathrm{I})$ specifically and that, under the concentrations used, BCA cannot compete with $\mathrm{ECuC}$ for $\mathrm{Cu}(\mathrm{I})$. In contrast, competition for $\mathrm{Cu}(\mathrm{I})$ was observed between $\mathrm{ECuC}$ and $\left[\mathrm{Cu}^{\mathrm{I}}(\mathrm{BCS})_{2}\right]^{3-}$, as indicated from the incomplete bleaching of the absorbance maxima at $483 \mathrm{~nm}$ for the $\left[\mathrm{Cu}^{\mathrm{I}}(\mathrm{BCS})_{2}\right]^{3-}$ complex (inset of Figure 3B). Analysis of these data using eqn (2) with a $\beta_{2}$ of $10^{19.8} \mathrm{M}^{-2}$ for $\left[\mathrm{Cu}^{\mathrm{I}}(\mathrm{BCS})_{2}\right]^{3-}$ gave a $K_{\mathrm{d}}\left(\mathrm{Cu}^{\mathrm{I}}\right)$ of $1.9 \times 10^{-16} \mathrm{M}$, which was used to simulate a fit of the data, shown by the unbroken line in Figure 3(B). Multiple datasets were obtained with various $\left[\mathrm{Cu}^{\mathrm{I}}\right]_{\text {total }}$ or [BCS], and an average $K_{\mathrm{d}}\left(\mathrm{Cu}^{\mathrm{I}}\right)$ for $\mathrm{ECuC}$ reported in Table 2 was obtained. The subfemtomolar affinity of $\mathrm{Cu}(\mathrm{I})$ for $\mathrm{ECuC}$ is thus in keeping with a putative $\mathrm{Cu}$ chaperone role. Addition of $\mathrm{Cu}(\mathrm{II})$ to $\mathrm{ECuC}$ under aerobic or anaerobic conditions led consistently to the formation of $\mathrm{Cu}(\mathrm{I})-\mathrm{ECuC}$.

\section{Structure of the $\mathrm{Cu}(\mathrm{I})$-bound and apo form of ECuC}

A single protein molecule was found in the crystallographic asymmetric unit of a crystal of $\mathrm{Cu}(\mathrm{I})-\mathrm{ECuC}$, with continuous and well-defined electron density for residues 51-164. The overall structure of $\mathrm{Cu}(\mathrm{I})-\mathrm{ECuC}$ is shown in Figure 4(A) and consists of a $\beta$-barrel-type fold comprising ten $\beta$-strands. Analysis of the structure in PDBeFold revealed only one protein with a high structural homology (0.6 compared with 0.27 Q-score for the next hit), indicating that $\mathrm{ECuC}$ has a high degree of structural homology with the solution NMR structure of $\mathrm{PCu}_{\mathrm{A}} \mathrm{C}$ from $T$. thermophilus. A single $\mathrm{Cu}$ site is located in a small dish-shaped region of $\beta$-structure on the exterior of the $\beta$-barrel involving $\beta$-sheets 4,5 and 8 (Figure $4 \mathrm{~B}$ ). The $\mathrm{Cu}(\mathrm{I})$ ion is co-ordinated by four residues, comprising $\mathrm{His}^{98}(\beta$-sheet 4$), \mathrm{Met}^{105}$ ( $\beta$-sheet 5 ) and two residues from $\beta$-sheet 8, His ${ }^{127}$ and Met $^{129}$ (Figure 4B). The bond lengths between the ligands and $\mathrm{Cu}(\mathrm{I})$ ion are reported in Table 3, along with the bond angles, which are suggestive of a distorted tetrahedral geometry. An X-ray fluorescence edge scan of a $\mathrm{Cu}(\mathrm{I})-\mathrm{ECuC}$ crystal gave a shoulder at $\sim 8980 \mathrm{eV}$ that is distinctly different in shape and energy $(8984 \mathrm{eV})$ to digonally or trigonally co-ordinated $\mathrm{Cu}(\mathrm{I})$ species and also in energy (8988-
$8990 \mathrm{eV}$ ) to tetrahedral $\mathrm{Cu}(\mathrm{II})$ species (Supplementary Figure S1 at http://www.biochemj.org/bj/459/bj4590525add.htm). The two methionine $\mathrm{Cu}$ ligands are solvent-exposed with their $\mathrm{C} \gamma$ atoms present at the protein surface, whereas the two histidine residues are buried and act to 'push' the $\mathrm{Cu}$ atom up and away from the dish-shaped region (Figure 4B). Neither of the two methionine ligands have any further interactions, whereas one of two histidine ligands, $\mathrm{His}^{98}$, has a hydrogen bond from its $\mathrm{N} \varepsilon 2$ atom to a water molecule.

The crystal structure of apo-ECuC also comprises one molecule in the crystallographic asymmetric unit, with well-defined electron density visible for residues 48-164. Superimposition of the $\mathrm{Cu}(\mathrm{I})$ and apo-structures, as shown in Figure $4(\mathrm{C})$, does not reveal any major differences, with an RMSD in C $\alpha$ positions of $0.4 \AA$. Subtle differences are noted, however, and are confined to the end of $\beta$-sheet 4 and to a slight lengthening of $\beta$-sheet 5 in the apo-structure (Figure $4 \mathrm{C}$ ). In the absence of $\mathrm{Cu}(\mathrm{I})$ the ligand residues are now considerably more dynamic, with multiple side-chain alternative conformations being modelled into the electron-density map (Figure 4D). The exception being His ${ }^{98}$, where a single imidazole ring conformer is modelled which is rotated $90^{\circ}$ relative to its orientation in the $\mathrm{Cu}(\mathrm{I})-\mathrm{ECuC}$ structure and the hydrogen-bond interaction through the $\mathrm{N} \varepsilon 2$ atom to a water molecule remains. The extent of the changes in side-chain orientations between the $\mathrm{Cu}(\mathrm{I})$-bound $\mathrm{ECuC}$ and apo- $\mathrm{ECuC}$ are indicated from the superimposition of the $\mathrm{Cu}$ site in Figure 4(E).

\section{$\mathrm{Cu}(\mathrm{I})$ binds to $\mathrm{Sco}^{\mathrm{SI}}$ with a higher affinity than to ECuC}

$\mathrm{Sco}^{\mathrm{Sl}}$ has been previously reported to bind a $\mathrm{Cu}(\mathrm{II})$ ion with high affinity $\left(K_{\mathrm{d}}>10^{-12} \mathrm{M}\right)$ and it has subsequently been shown that it is the cupric oxidation state that is required for its role in the $\mathrm{Cu}-$ dependent morphological development switch of S. lividans and in metallating $\mathrm{CcO}$ [26]. Before assessing whether $\mathrm{Cu}$ transfer between $\mathrm{ECuC}$ and $\mathrm{Sco}^{\mathrm{Sl}}$ can occur, $\mathrm{Cu}(\mathrm{I})$ binding to $\mathrm{Sco}^{\mathrm{Sl}}$ has been investigated. At $\mathrm{pH} 7.5$, addition of increasing amounts of reduced apo-Sco ${ }^{\mathrm{Sl}}$ into $\left[\mathrm{Cu}^{\mathrm{I}}(\mathrm{BCA})_{2}\right]^{3-}$ revealed that $\mathrm{BCA}$ cannot compete with apo-Sco ${ }^{\text {sl }}$ for $\mathrm{Cu}(\mathrm{I})$ under the concentrations used and one $\mathrm{Cu}(\mathrm{I})$ ion binds per monomer of $\mathrm{Sco}^{\mathrm{Sl}}$ (Figure 3C). Using $\left[\mathrm{Cu}^{\mathrm{I}}(\mathrm{BCS})_{2}\right]^{3-}$, competition for $\mathrm{Cu}(\mathrm{I})$ between $\mathrm{Sco}^{\mathrm{Sl}}$ and $\mathrm{BCS}$ is observed (Figure 3D). Analysis of these data using eqn (2) with a $\beta_{2}$ of $10^{19.8} \mathrm{M}^{-2}$ for $\left[\mathrm{Cu}^{\mathrm{I}}(\mathrm{BCS})_{2}\right]^{3-}$ gave a $K_{\mathrm{d}}\left(\mathrm{Cu}^{\mathrm{I}}\right)$ of $6.5 \times 10^{-17}$ $\mathrm{M}$, which was used to simulate a fit of the data, shown by the unbroken line in Figure 3(D). Multiple datasets were obtained with various $\left[\mathrm{Cu}^{\mathrm{I}}\right]_{\text {total }}$ or $[\mathrm{BCS}]$ and an average $K_{\mathrm{d}}\left(\mathrm{Cu}^{\mathrm{I}}\right)$ for reduced apo-Sco ${ }^{\mathrm{Sl}}$ at $\mathrm{pH} 7.5$ is reported in Table 2, indicating an $\sim 4$-fold higher affinity for $\mathrm{Cu}(\mathrm{I})$ than $\mathrm{ECuC}$.

\section{Structure of the C90A mutant of Sco ${ }^{\mathrm{SI}}$}

The overall structure of the C90A mutant of $\mathrm{ScO}^{\mathrm{Sl}}$ is shown in Figure 5(A). All efforts to crystallize the WT protein in the presence and absence of $\mathrm{Cu}$ were unsuccessful. The $\mathrm{C} 90 \mathrm{~A}$ mutant has been previously studied in respect to the kinetics and mechanism of $\mathrm{Cu}$ (II) capture by the $\mathrm{Cys}^{86} \mathrm{xxxCys}^{90}$ motif in $\mathrm{Sco}^{\mathrm{S1}}$ [30]. A single protein molecule was found in the crystallographic asymmetric unit of a crystal of $\mathrm{Sco}^{\mathrm{Sl}} \mathrm{C} 90 \mathrm{~A}$. The monomeric fold consists of five $\alpha$-helices one $3_{10}$ helix and eight $\beta$-strands, with strands $\beta 4, \beta 5, \beta 7$ and $\beta 8$, and helices $\alpha 1, \alpha 4$ and $\alpha 5$ forming the core of a typical thioredoxin fold (Figure 5A). Typical of other Sco proteins, additional secondary structure is inserted at the $\mathrm{N}$-terminus. A long twisted $\beta$-strand $(\beta 1)$ is present, which is either absent or considerably shorter in other known structures of Sco proteins and wraps around the core $\beta 7$ and $\beta 8$ strands 

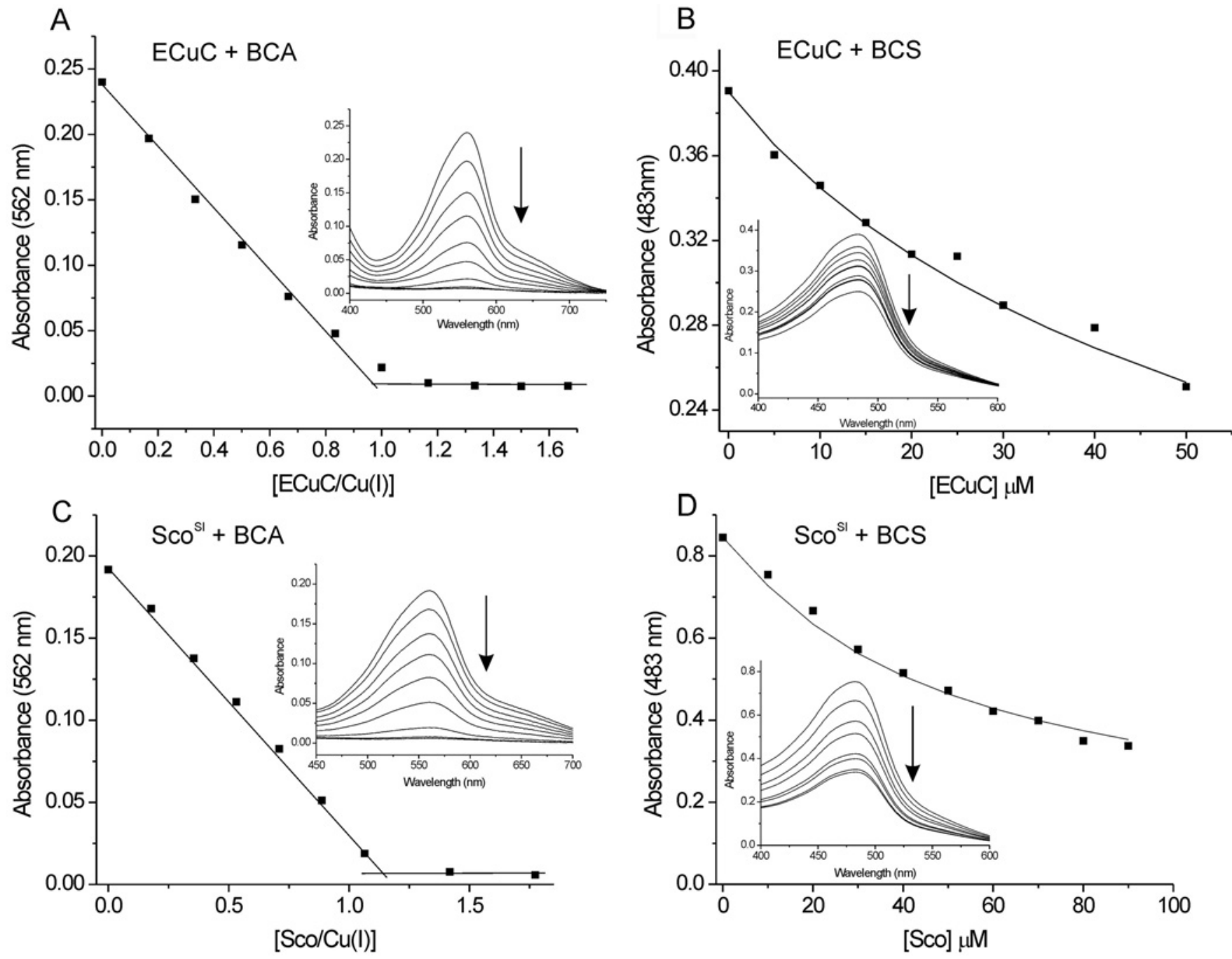

Figure 3 Determination of the $\mathrm{Cu}(\mathrm{I})$ stoichiometry and $K_{\mathrm{d}}\left(\mathrm{Cu}^{\prime}\right)$ for $S$. lividans $\mathrm{ECuC}$ and $\mathrm{Sco}{ }^{\mathrm{SI}}$ at $\mathrm{pH} 7.5$ using the chromogenic probes $\mathrm{BCA}$ and $\mathrm{BCS}$

(A) Plot of the absorbance change at $562 \mathrm{~nm}$ in the $\left[\mathrm{Cu}^{\prime}(\mathrm{BCA})_{2}\right]^{3-}$ spectrum (inset) as a function of [ECuC]:[Cu(I)]. No competition between ECuC and BCA is observed on the basis that the absorbance at $562 \mathrm{~nm}$ decreases to zero with increasing amounts of ECuC. The intersections of the lines at the start and end of the titration indicate a stoichiometry of Cu(I) binding to ECuC of $\sim 1$. Conditions used: $0-50 \mu \mathrm{M}[\mathrm{ECuC}], 30 \mu \mathrm{M}[\mathrm{Cu}]_{\text {total }}$ and $120 \mu \mathrm{M}[\mathrm{BCA}]$. (B) Plot of the absorbance change at $483 \mathrm{~nm}$ in the $\left[\mathrm{Cu}^{\prime}(\mathrm{BCS})_{2}\right]^{3-}$ spectrum (inset) under Cu(I)-limiting conditions imposed by $\left[\mathrm{Cu}(\mathrm{BCS})_{2}\right]^{3-}$ as a competitive probe as a function of [ECuC]. The line through the data points represents a best fit using a $K_{d}\left(\mathrm{Cu} \mathbf{U}^{\prime}\right)$ of $1.9 \times 10^{-16} \mathrm{M}$ determined using eqn $(2)$.

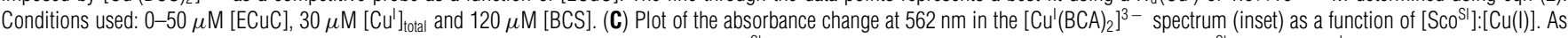
for ECuC, no competition with BCA is observed and a stoichiometry of Cu(I) binding to Scosl of $\sim 1$ is determined. Conditions used: $0-45 \mu \mathrm{M}\left[S \mathrm{Sc}^{\mathrm{SI}}\right], 25 \mu \mathrm{M}$ [Cu'] $]_{\text {total }}$ and $75 \mu \mathrm{M}[\mathrm{BCA}]$. (D) Plot of the absorbance change at $483 \mathrm{~nm}$ in the $\left[\mathrm{Cu}^{\prime}(\mathrm{BCS})_{2}\right]^{3-}$ spectrum (inset) under $\mathrm{Cu}(\mathrm{I})$-limiting conditions imposed by $\left[\mathrm{Cu}^{\prime}(\mathrm{BCS})_{2}\right]^{3-}$ as a competitive probe as a function of $\left[\mathrm{SCO}^{\mathrm{Sl}}\right]$. The line through the data points represents a best fit using a $K_{d}\left(\mathrm{Cu}^{\prime}\right)$ of $6.5 \times 10^{-17} \mathrm{M}$ determined using eqn (2). Conditions used: $0-90 \mu \mathrm{M}\left[\mathrm{SC} 0^{\mathrm{SI}}\right]$, $65 \mu \mathrm{M}[\mathrm{Cu}]_{\text {total }}$ and $150 \mu \mathrm{M}[\mathrm{BCS}$ ].

of the thioredoxin fold (Figure 5A). Following on from $\beta 1$ is the conserved $\beta$-hairpin structure $(\beta 2+\beta 3)$ and a $3_{10}$ helix (Figure 5A). A second insertion of secondary structure on to the thioredoxin scaffold is found between $\beta 5$ and $\alpha 4$ and consists of the helix $\alpha 3$ and the stand $\beta 6$ and finally, unique to $\mathrm{Sco}^{\mathrm{S1}}$, a short $\alpha$-helix $(\alpha 2)$ is inserted between $\alpha 1$ and $\beta 5$ (Figure 5A). Analysis of the structure using PDBeFold reveals the highest structural homology (0.59 Q-score) with the solution NMR structure of the Sco protein from $T$. thermophilus followed by the Sco proteins from yeast and human (0.54 and 0.53 Q-scores respectively). The electron density is continuous from residues 42-164 and 177-216, with the region between amino acids 165 and 176 having discontinuous electron density and, as a consequence, these 12 residues are not included in the model (Figure 5A). This observation is indicative of a flexible dynamic protein region and is consistent with reports that the loop connecting $\alpha 4$ to $\beta 7$, referred to as the 'Sco-loop', is dynamic and flexible and thus gives rise to disorder in the C90A crystal. Within this missing 12-residue stretch, $\mathrm{His}^{176}$ is located, a residue which has been previously shown in $\mathrm{Sco}^{\mathrm{Sl}}$ to act as a co-ordinating ligand to the $\mathrm{Cu}(\mathrm{II})$ ion bound to the $\mathrm{CxxxC}$ motif [26].

An unexpected feature of the C90A structure is that the electron density for the $\mathrm{Cys}^{86}$ side chain is suggestive of a modification (Figure 5B). We modelled a sulfinic and sulfonic acid functional group at this position and found that the former, with two oxygen atoms, provides the best fit to the electron density (Figure 5B). ESI-MS of the C90A sample before crystallization gave a mass as expected and therefore this oxidizing modification must have either taken place over time during the crystallization process or possibly in the X-ray beam. As a consequence of this modification, the oxygen atoms of the sulfinic group are able to form hydrogen bonds with the backbone amide of $\mathrm{Asp}^{88}$ and $\mathrm{Ala}^{90}$ and thus 
Table $2 \mathrm{Cu}(\mathrm{I})$ affinities determined at $\mathrm{pH} 7.5$ for ECuC, $\mathrm{Sco}^{\mathrm{SI}}$ and $\mathrm{Sco}^{\mathrm{SI}}$ variants and $\mathrm{p} K_{\mathrm{Cys}}$ and $\Delta \varepsilon$ values at $240 \mathrm{~nm}$ for the respective $\mathrm{Sco}{ }^{\mathrm{SI}} \mathrm{proteins}$

\begin{tabular}{llllll}
\hline Protein & $K_{\mathrm{d}}(\mathrm{Cu})(\mathrm{M})$ & $p K_{\text {cys } 1}$ & $p K_{\text {cys2 }}$ & $\Delta \varepsilon_{1}\left(\mathrm{mM}^{-1} \cdot \mathrm{cm}^{-1}\right)$ & $\Delta \varepsilon_{2}\left(\mathrm{mM}^{-1} \cdot \mathrm{cm}^{-1}\right)$ \\
\hline ECuC & $2.0(0.2) \times 10^{-16}$ & - & - & - & - \\
Sc0 & $4.6(1.4) \times 10^{-17}$ & $6.22(0.11)$ & $8.90(0.46)$ & $3.2(0.4)$ & $1.1(0.1)$ \\
C86A & $8.3(1.3) \times 10^{-14}$ & $6.34(0.32)$ & - & $2.3(0.2)$ & - \\
C90A & $2.8(1.3) \times 10^{-16}$ & $6.54(0.41)$ & - & $2.7(0.2)$ & - \\
H176A & $1.5(0.8) \times 10^{-14}$ & $6.56(0.13)$ & $8.90(0.45)$ & $3.1(0.1)$ & $2.0(0.3)$
\end{tabular}
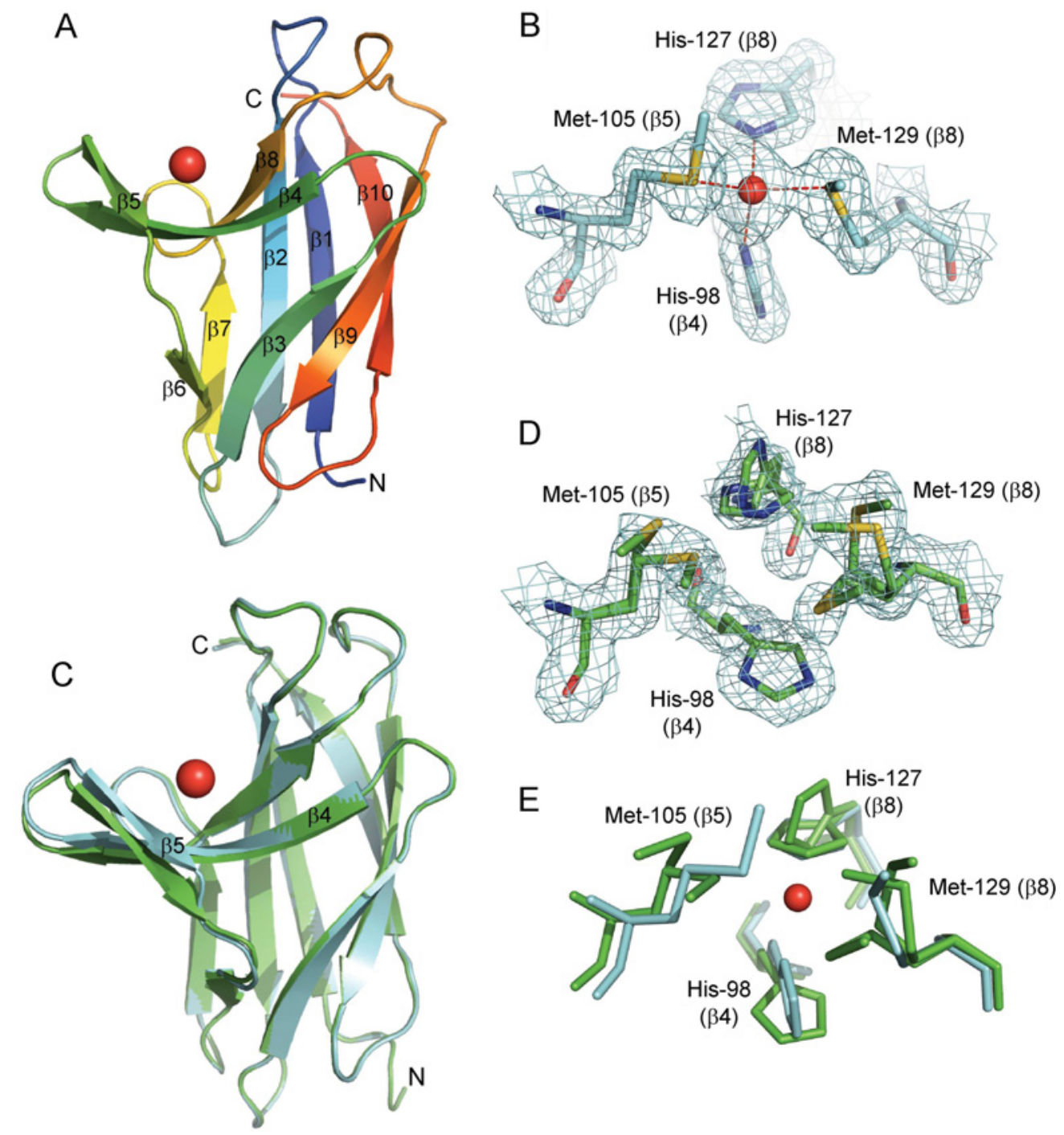

Figure 4 X-ray crystal structure of $S$. lividans ECuC

(A) Cartoon representation of $\mathrm{Cu}(\mathrm{I})-\mathrm{ECuC}$ with the $\mathrm{Cu}$ ion shown as a red sphere. The $\beta$-strands $1-10$ are labelled and the positions of the $\mathrm{N}$ - and $\mathrm{C}$-termini are indicated. (B) $2 F_{0}-F_{\mathrm{c}}$ electron-density map contoured at $1 \sigma$ of the $\mathrm{Cu}(\mathrm{I})$-binding site of ECuC with the ligands to the $\mathrm{Cu}(\mathrm{I})$ ion and their $\beta$-strand location indicated. (C) Superimposition (calculated in the CCP4 suite) of the $\mathrm{C} \alpha$ atoms of the $\mathrm{Cu}(\mathrm{l})-\mathrm{ECuC}$ structure (cyan) with the apo-ECuC structure (green). The $\mathrm{N}$ - and $\mathrm{C}$-termini are indicated as well as the $\beta 4$ and $\beta 5$ strands where significant structural changes occur between the two structures. (D) $2 F_{0}-F_{c}$ electron-density map contoured at $1 \sigma$ of the $\mathrm{Cu}(I)$ site ligands in the apo-ECuC structure with the multiple orientations of the side chains built into the density for each ligand shown. (E) Superimposition of the Cu(I)-ECuC and apo-ECuC Cu-binding sites.

serve to add stability to the loop harbouring the CxxxC motif (Figure 5B). In the absence of this modification, it is highly unlikely that the thiol group of $\mathrm{Cys}^{86}$ will participate in any hydrogen-bond interactions. A superimposition of the Cys ${ }^{86}$ loop region between different prokaryotic Sco proteins is shown in Figure 5(C), with positional differences in the loop between proteins from different species clearly apparent. The most notable is the position of the cysteine residue in $\mathrm{Sco}^{\mathrm{Bs}}$ (equivalent to $\mathrm{Cys}^{90}$ in $\mathrm{Sco}^{\mathrm{Sl}}$ ) (Figure 5C). In all of the other structures, the second cysteine residue of the $\mathrm{CxxxC}$ motif is the second residue in helix $\alpha 1$, whereas in $\mathrm{Sco}^{\mathrm{Bs}}$ it remains highly solvent-exposed on the loop (Figure 5C). This would appear to be a consequence of the loop length being largest for $\mathrm{Sco}^{\mathrm{Bs}}$ and shorter among the other species. 
Table 3 Bond lengths and angles for the $\mathrm{Cu}(\mathrm{I})$ site of S. lividans ECuC (a) Bond length

\begin{tabular}{|c|c|}
\hline Bond & Length $(\AA)$ \\
\hline $\mathrm{Cu}-\mathrm{His}^{98} \mathrm{~N} \delta 1$ & 2.15 \\
\hline $\mathrm{Cu}-\mathrm{Met}^{105} \mathrm{~S} \delta$ & 2.25 \\
\hline $\mathrm{Cu}-\mathrm{His}^{127} \mathrm{~N} \varepsilon 2$ & 2.08 \\
\hline Cu-Met ${ }^{129} \mathrm{~S} \delta$ & 2.31 \\
\hline \multicolumn{2}{|l|}{ (b) Bond angle } \\
\hline Bond & Angle $\left({ }^{\circ}\right)$ \\
\hline $\mathrm{His}^{98} \mathrm{~N} \delta 1-\mathrm{Cu}-\mathrm{Met}^{105} \mathrm{~S} \delta$ & 113.6 \\
\hline $\mathrm{His}^{98} \mathrm{~N} \delta 1-\mathrm{Cu}-\mathrm{His}^{127} \mathrm{~N} \varepsilon 2$ & 108.3 \\
\hline $\mathrm{His}^{98} \mathrm{~N} \delta 1-\mathrm{Cu}-\mathrm{Met}^{129} \mathrm{~S} \delta$ & 109.9 \\
\hline $\mathrm{Met}^{105} \mathrm{~S} \delta-\mathrm{Cu}-\mathrm{His}^{127} \mathrm{~N} \varepsilon 2$ & 109.9 \\
\hline $\mathrm{Met}^{105} \mathrm{~S} \delta-\mathrm{Cu}-\mathrm{Met}^{129} \mathrm{~S} \delta$ & 115.3 \\
\hline $\mathrm{His}^{127} \mathrm{~N} \varepsilon 2-\mathrm{Cu}-\mathrm{Met}^{129} \mathrm{~S} \delta$ & 98.7 \\
\hline
\end{tabular}

\section{$\mathrm{Cu}(\mathrm{I})-\mathrm{ECuC}$ can transfer $\mathrm{Cu}$ to $\mathrm{Sco}^{\mathrm{SI}}$}

To assess whether $\mathrm{ECuC}$ and $\mathrm{Sco}^{\mathrm{Sl}}$ can participate in $\mathrm{Cu}(\mathrm{I})$ ion transfer with each other, tryptophan fluorescence was used. A single tryptophan residue, $\operatorname{Trp}^{132}$, is present in $\mathrm{Sco}^{\mathrm{Sl}}$, whereas $\mathrm{ECuC}$ has no tryptophan residues. The crystal structure of $\mathrm{Sco}^{\mathrm{Sl}}$ C90A reveals that $\operatorname{Trp}^{132}$ is located on helix $\alpha 3$ and is within $6 \AA$ of the backbone amide of $\mathrm{Cys}^{86}$ (inset of Figure 6A). Binding of either $\mathrm{Cu}(\mathrm{II})$ or $\mathrm{Cu}(\mathrm{I})$ to the $\mathrm{CxxxC}$ motif in $\mathrm{Sco}^{\mathrm{Sl}}$ leads to a quenching of the tryptophan emission intensity at $330 \mathrm{~nm}$ [26], as indicated in Figure 6(A), and thus $\operatorname{Trp}^{132}$ serves as a sensitive probe to follow $\mathrm{Cu}$ ion binding to $\mathrm{Sco}^{\mathrm{Sl}}$. Mixing both apo-proteins in a 1:1 stoichiometry has no effect on the $\operatorname{Trp}^{132}$ emission spectrum of $\mathrm{Sco}^{\mathrm{Sl}}$ over a period of hours (Figure 6B).
In contrast, the addition of a stoichiometric equivalent of $\mathrm{Cu}(\mathrm{I})-$ $\mathrm{ECuC}$ to apo-Sco ${ }^{\mathrm{Sl}}$ causes rapid instantaneous quenching in the emission spectrum (Figure 6C and inset) and indicates that $\mathrm{Cu}$ is now bound to $\mathrm{Sco}^{\mathrm{Sl}}$. As no other source of $\mathrm{Cu}$ ions were present in solution, this is clear evidence that $\mathrm{Cu}$ is transferred from $\mathrm{ECuC}$ to $\mathrm{Sco}^{\mathrm{Sl}}$. From the fluorescence quenching it was not possible to identify the oxidation state of the $\mathrm{Cu}$ bound to $\mathrm{Sco}{ }^{\mathrm{Sl}}$ following the transfer. However, no characteristic $\mathrm{Cu}(\mathrm{II})-\mathrm{Sco}^{\mathrm{SI}}$ absorbance bands were present in the visible spectrum [26] of the mixture and it was therefore concluded that $\mathrm{Cu}$ was transferred and remained bound to $\mathrm{Sco}^{\mathrm{Sl}}$ in the cuprous state. The reverse experiment, whereby $\mathrm{Cu}(\mathrm{I})-\mathrm{Sco}^{\mathrm{Sl}}$ was mixed stoichiometrically with apo-ECuC did not yield an increase in the emission intensity of the tryptophan fluorescence spectrum, which would have be expected to occur if $\mathrm{Cu}$ was being transferred from $\mathrm{Sco}^{\mathrm{Sl}}$ to $\mathrm{ECuC}$ (Figure 6D). These results therefore reveal that $\mathrm{Cu}(\mathrm{I})$ is transferred in a unidirectional manner from $\mathrm{ECuC}$ to $\mathrm{Sco}^{\mathrm{Sl}}$ and, for transfer to occur, a complex between the two proteins must therefore be formed. Figure 7 shows surface electrostatic maps of $\mathrm{Cu}(\mathrm{I})-\mathrm{ECuC}$ and $\mathrm{Sco}^{\mathrm{Sl}} \mathrm{C} 90 \mathrm{~A}$ where it is apparent that both proteins have a significant overall negative charge (theoretical pI values of 4.8 and 5.0 for $\mathrm{ECuC}$ and $\mathrm{Sco}^{\mathrm{Sl}}$ constructs used respectively). Nevertheless, a complementary charged patch is observed between the region around the $\mathrm{Cu}(\mathrm{I})$ site of $\mathrm{ECuC}$ and the $\mathrm{CxxxC}$ region of $\mathrm{Sco}^{\mathrm{Sl}}$ (Figure 7).

\section{Two distinct ionization processes for the cysteine residues in the CxxxC motif of Sco ${ }^{\text {sI }}$}

The ionization properties of cysteine thiol groups in Atx1-like metallochaperones that have a $\mathrm{CxxC}$ motif have been reported to be important for facilitating metal ion transfer $[49,50]$. To
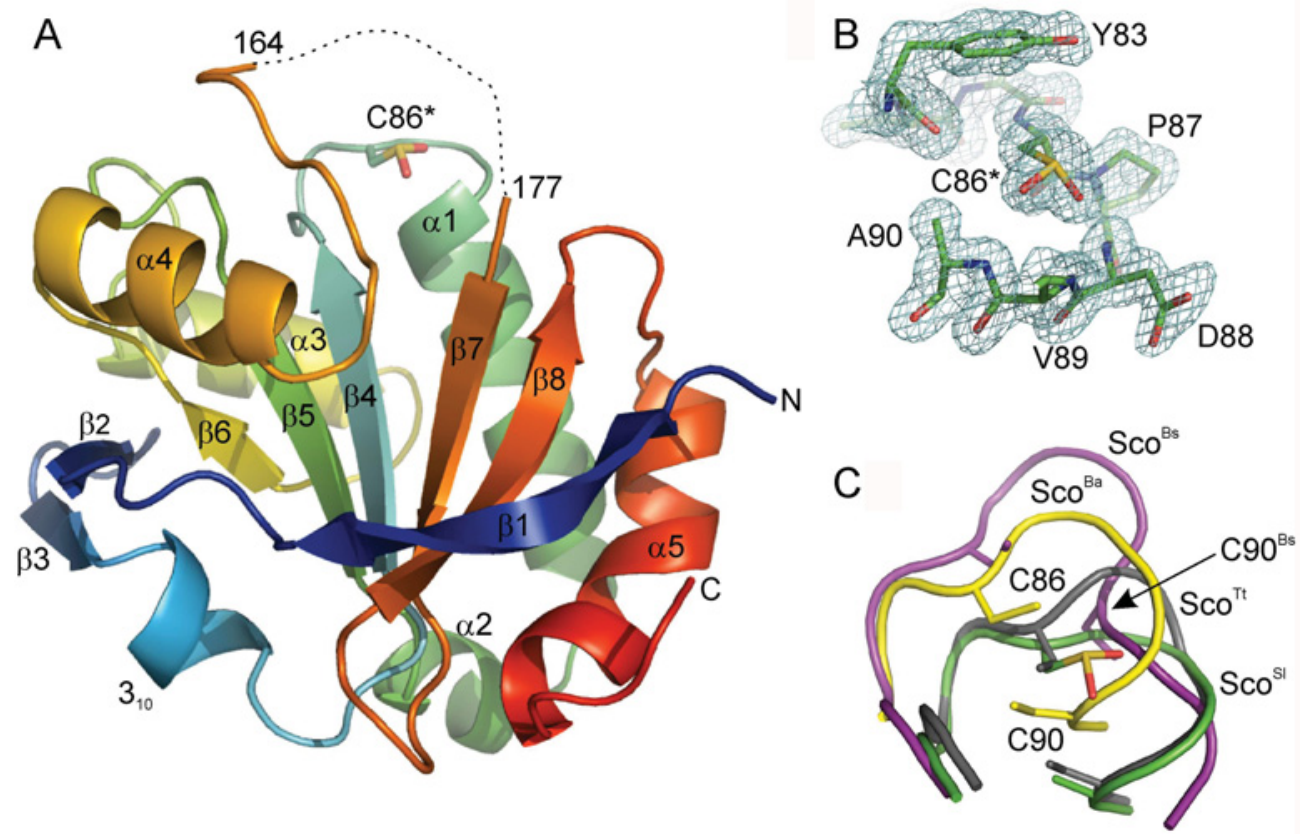

Figure 5 X-ray crystal structure of the C9OA mutant of $S_{C 0}{ }^{S I}$

(A) Cartoon representation of $\mathrm{S} \mathrm{Co}^{\mathrm{Sl}}$ with the secondary structure components that make up the fold labelled. The $\mathrm{N}$ - and $\mathrm{C}$-termini are indicated and the modified Cys ${ }^{86}$ residue, part of the $\mathrm{CxxxC}$ motif, is shown as sticks. The broken line connecting residues 164-177 is to illustrate the 'Sco-loop' that houses His ${ }^{176}$, a ligand in the Cu-bound form, that is not observable in this crystal structure. (B) $2 F_{0}-F_{c}$ electron-density map contoured at $1 \sigma$ of the CxxxC motif illustrating the modified thiol side chain of $\mathrm{Cys}^{86}$ and the position of Ala ${ }^{90}$. (C) Superimposition of the loop containing the CxxxC motif of Sco ${ }^{S l}$ with those in other prokaryotic Sco proteins (Bs, B. subtilis; Ba, B. anthracis; Tt, T. thermophilus). The cysteine residues 86 and 90 (S. lividans numbering) for each species are shown as sticks. 
A
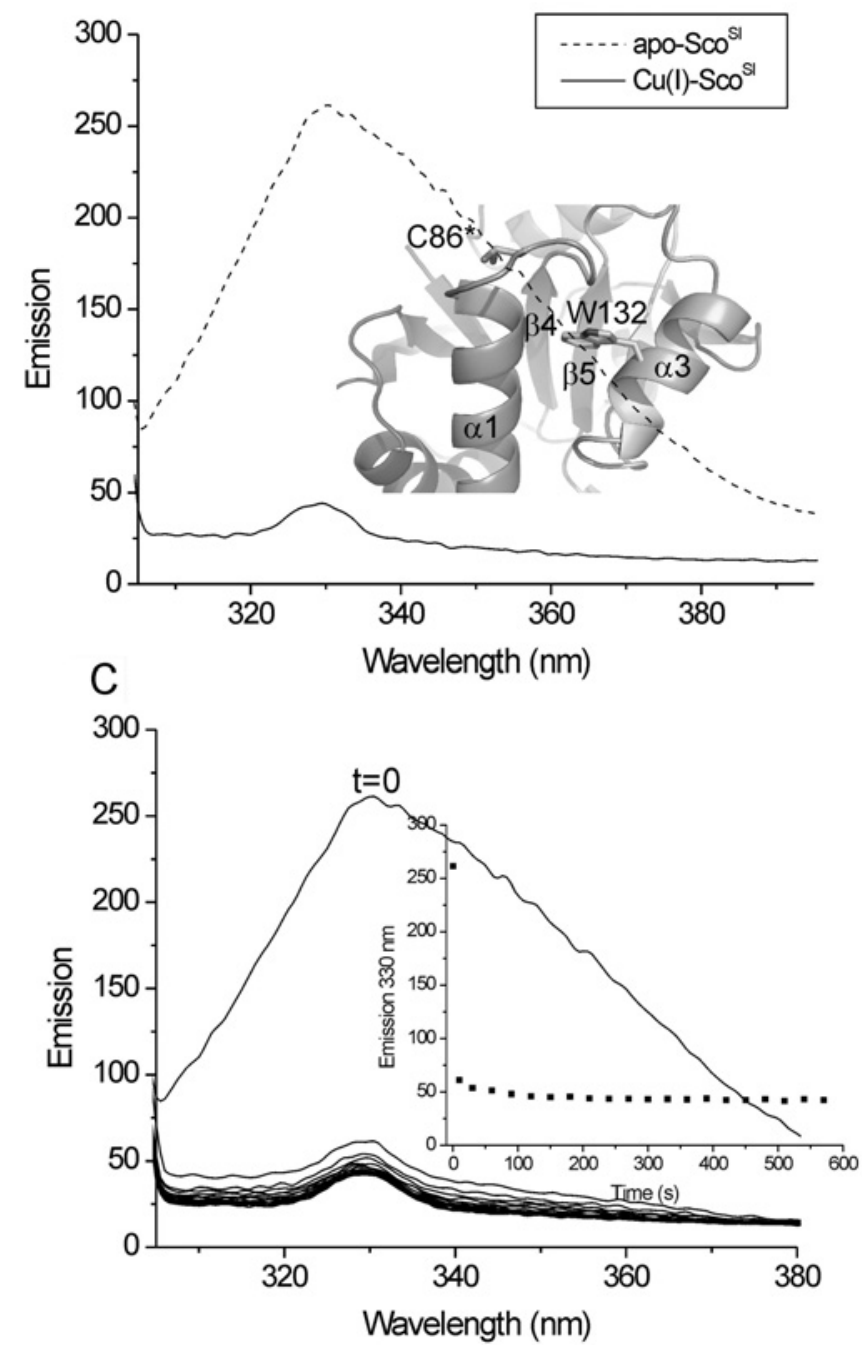

B
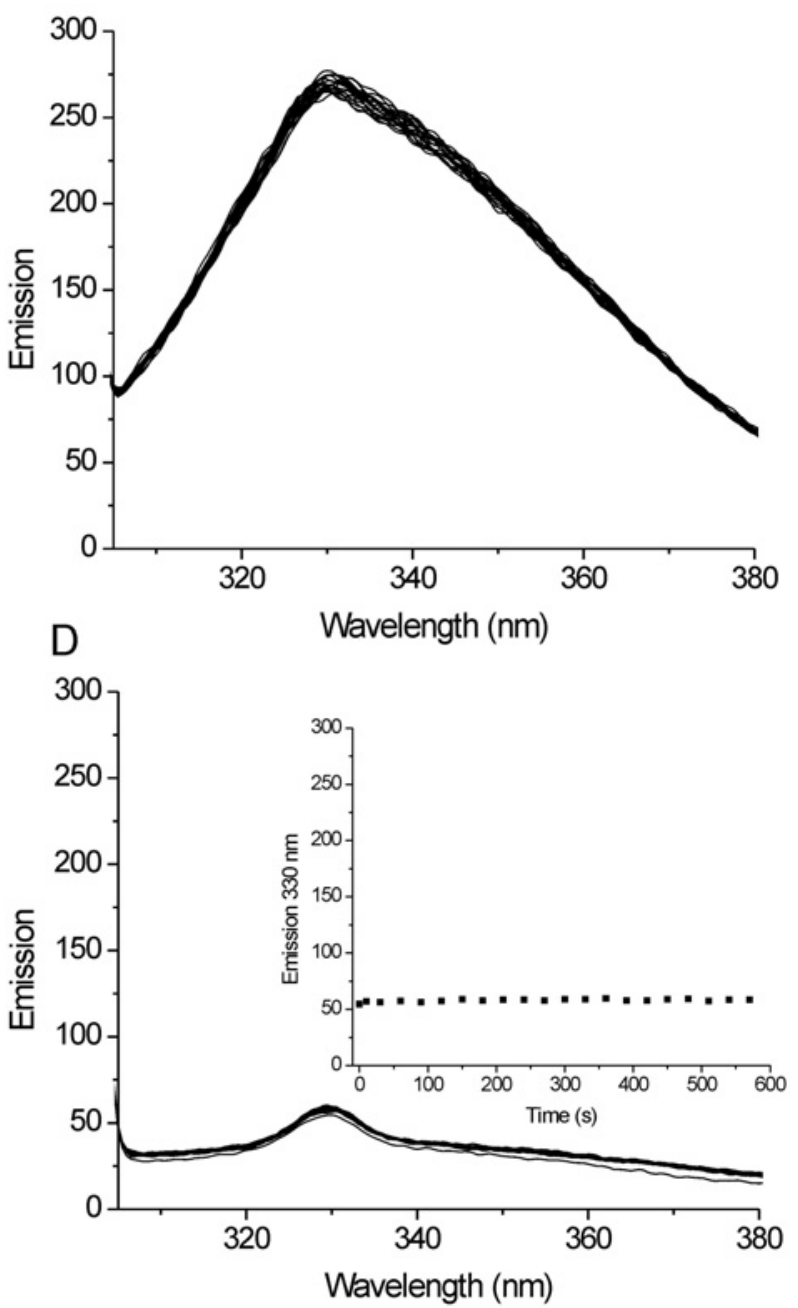

Figure 6 Cu transfer between ECuC and Sco ${ }^{\text {SI }}$ monitored by tryptophan fluorescence

(A) Structural location of $\operatorname{Trp}^{132}$ in $\mathrm{Sco}^{\mathrm{Sl}}$ and the quenching of the tryptophan emission spectrum of apo-Scosl upon a stoichiometric addition of Cu(I). (B) Tryptophan emission spectrum of apo-Sco ${ }^{\mathrm{Sl}}$ upon addition of a stoichiometric equivalent of apo-ECuC. (C) Quenching of the tryptophan emission of Sco ${ }^{S I}$ upon incubation of a molar equivalent of Cu(I)-ECuC. Inset, change in tryptophan emission at $330 \mathrm{~nm}$ as a function of time after addition of $\mathrm{Cu}(\mathrm{I})-\mathrm{ECuC}$. (D) Tryptophan emission spectrum of $\mathrm{Cu}(\mathrm{I})-\mathrm{Sc}{ }^{\mathrm{Sl}}$ in the presence of a molar equivalent of apo-ECuC. Inset, change in tryptophan emission at $330 \mathrm{~nm}$ as a function of time after addition of apo-ECuC. All experiments were carried out at $20^{\circ} \mathrm{C}$, pH 7.5, with excitation at $295 \mathrm{~nm}$.

gain further insight into the transfer of $\mathrm{Cu}(\mathrm{I})$ from $\mathrm{ECuC}$ to $\mathrm{Sco}^{\mathrm{Sl}}$, the $\mathrm{p} K_{\mathrm{a}}$ values of the cysteine residues in the $\mathrm{CxxxC}$ motif of $\mathrm{Sco}^{\mathrm{Sl}}$ were determined directly by monitoring the absorbance change at $240 \mathrm{~nm}$ as a function of $\mathrm{pH}$ (Figure 8A). The data fit best to a model involving two ionizations and the $\mathrm{p} K_{\text {Cys }}$ and $\Delta \varepsilon$ values are reported in Table 2. For one of the cysteine residues, a $\mathrm{p} K_{\mathrm{Cys}}$ of 6.3 indicates that at physiological $\mathrm{pH}$ the more nucleophilic thiolate form would predominate. The effects on $\mathrm{Cu}$ transfer between $\mathrm{ECuC}$ and $\mathrm{Sco}^{\mathrm{Sl}}$ were further assessed through the C86A, C90A and H176A mutants of $\mathrm{Sco}^{\mathrm{Sl}}$. All three mutants bound $\mathrm{Cu}(\mathrm{I})$ with affinities lower than the WT $\mathrm{Sco}^{\mathrm{Sl}}$ (Table 2, Figure 8B and Supplementary Figure S2 at http://www.biochemj.org/bj/459/bj4590525add.htm) and for the H176A mutant two ionization processes were detected (Supplementary Figure S3 at http://www.biochemj.org/ bj/459/bj4590525add.htm) with the $\mathrm{p} K_{\text {Cys }}$ values reported in Table 2 very similar to WT $\mathrm{Sco}^{\mathrm{Sl}}$. For the C86A and C90A mutants a single ionization process was detected (Figure $8 \mathrm{C}$ and
Supplementary Figure S3), with $\mathrm{p} K_{\mathrm{Cys}}$ values for each mutant similar to the lower of the two $\mathrm{p} K_{\text {Cys }}$ values determined in the WT and H176A proteins (Table 2). Thus removing one of the thiols appears to influence the $\mathrm{p} K_{\mathrm{a}}$ of the remaining thiol. We note that the $\Delta \varepsilon$ values determined for the individual cysteine residues in the two cysteine mutants differ (Table 2). This was also observed for the two ionization transitions in the WT and H176A proteins (Table 2). Therefore on the basis of this we propose that the lower $\mathrm{p} K_{\mathrm{Cys}}$ in the WT $\mathrm{Sco}^{\mathrm{Sl}}$, which has the greater $\Delta \varepsilon$, is for $\mathrm{Cys}^{86}$, as the C90A mutant consistently showed a greater $\Delta \varepsilon$, with the higher $\mathrm{p} K_{\mathrm{a}}$ assigned to $\mathrm{Cys}^{90}$ as the $\mathrm{C} 86 \mathrm{~A}$ mutant has the smaller $\Delta \varepsilon$. Such an interpretation has also been rationalized for the $\mathrm{Hg}^{2+}$ Atx1-like chaperone NmerA [49]. Addition of a stoichiometric amount of $\mathrm{Cu}(\mathrm{I})$ to the $\mathrm{H} 176 \mathrm{~A}$ mutant results in quenching of the $\operatorname{Trp}^{132}$ fluorescence, similar to that observed for WT Sco ${ }^{\mathrm{Sl}}$. Quenching is also observed, albeit more slowly, when one equivalent of $\mathrm{Cu}(\mathrm{I})-\mathrm{ECuC}$ is mixed with the $\mathrm{H} 176 \mathrm{~A}$ mutant and thus $\mathrm{Cu}$ transfer is still viable in the absence of $\mathrm{His}^{176}$ in $\mathrm{Sco}^{\mathrm{Sl}}$. 


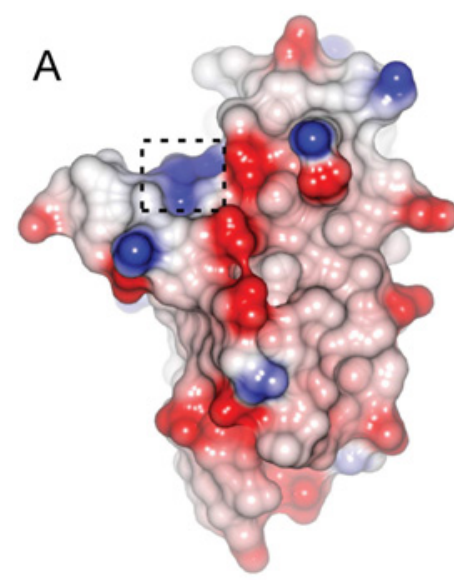

B

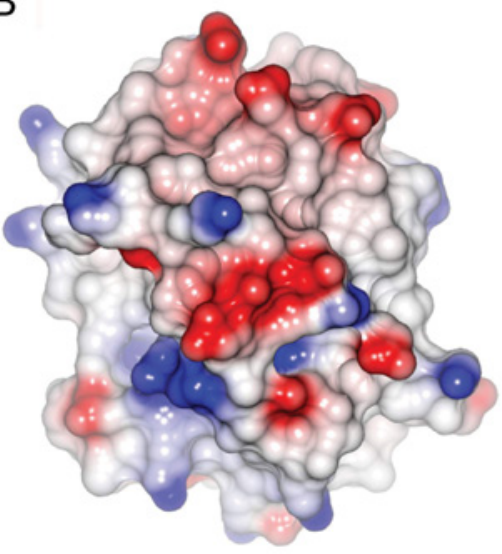

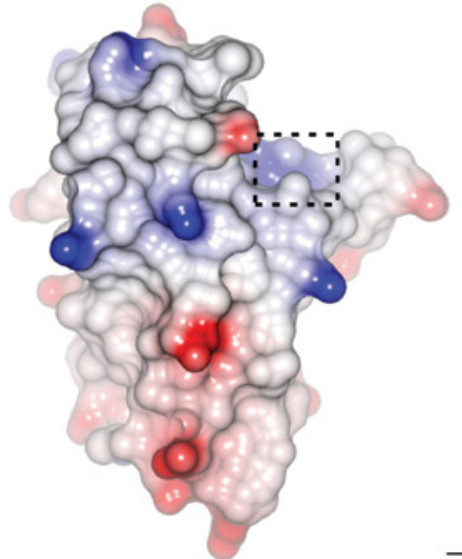
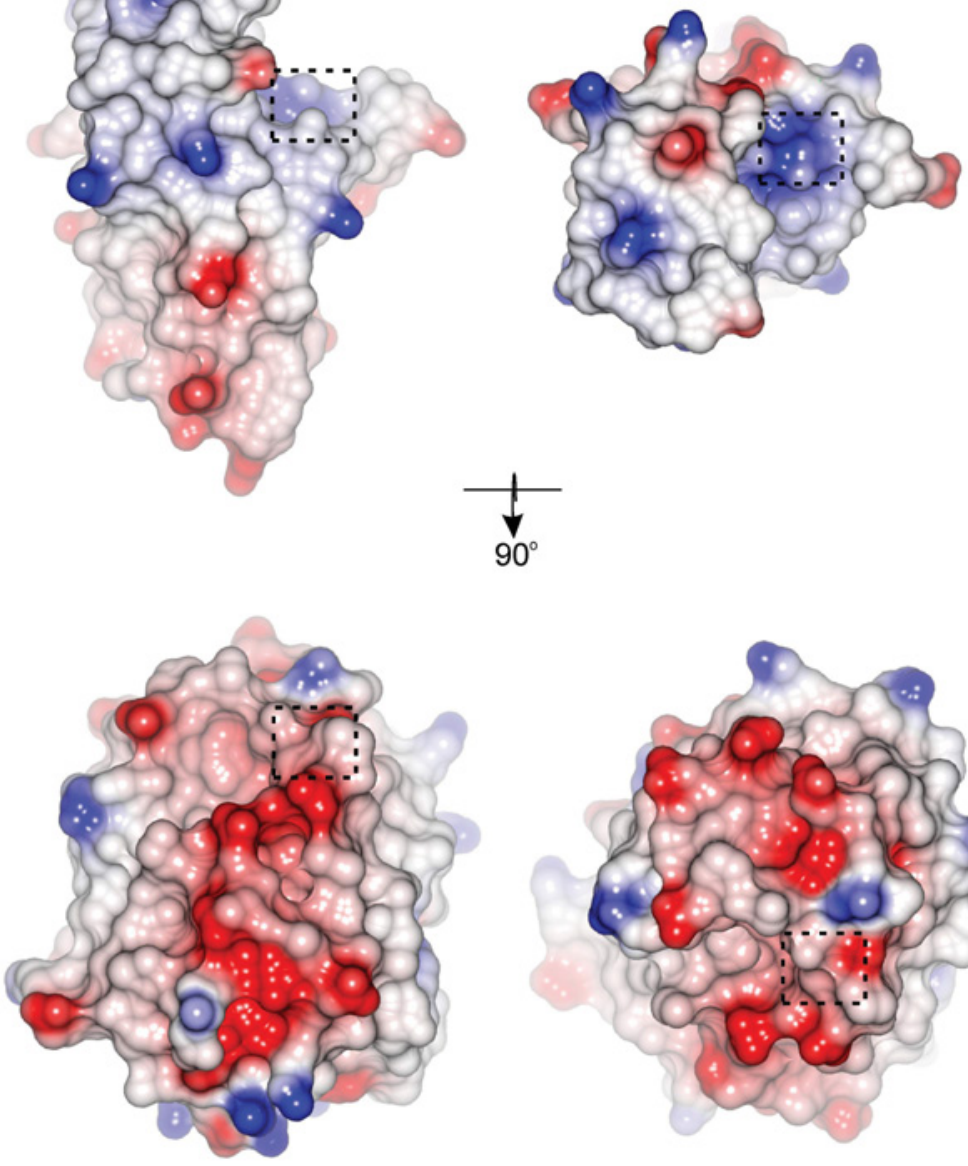

Figure 7 Electrostatic surface representations of (A) Cu(I)-ECuC and (B) ScosI (C9OA)

Positive charges are indicated in blue and negative charges are indicated in red. The broken box highlights the location of the $\mathrm{Cu}(\mathrm{I})$ site in ECuC and the $\mathrm{CxxxC}$ motif in Sco ${ }^{\mathrm{Sl}}$.

The situation with the cysteine mutants is complicated by the fact that removal of either cysteine residue alters the fluorescence properties of $\mathrm{Cu}$ binding, such that at sub- and stoichiometric $\mathrm{Cu}$ concentrations no quenching is observed, despite $\mathrm{Cu}$ being bound to the protein [30]. Therefore on mixing $\mathrm{Sco}^{\mathrm{Sl}} / \mathrm{Cu}(\mathrm{I})-\mathrm{ECuC}$ under stoichiometric conditions, no quenching was observed and the effect of either cysteine residue on transfer is not determinable.

\section{Morphological development and $\mathrm{CcO}$ activity}

The above in vitro experiments provide strong evidence that $\mathrm{Cu}(\mathrm{I})$ can be transferred from $\mathrm{ECuC}$ to $\mathrm{Sco}^{\mathrm{Sl}}$. To assess the effect of ECuC on morphological development, ecuc and scolecuc knockouts were created in S. lividans 1326 and the morphological development monitored on R5 medium with various $[\mathrm{Cu}]$ (Figure 9A). As previously reported, the sco mutant is incapable of switching from vegetative to aerial growth and spore production at low [Cu] [0.1 or $1 \mu \mathrm{M} \mathrm{Cu}(\mathrm{II})]$, with full development restored upon addition of $10 \mu \mathrm{M} \mathrm{Cu}$ (II) (Figure 9A). By contrast the ecuc mutant showed full development at low $[\mathrm{Cu}]$ comparable with that observed in the WT strain (Figure 9A). The double scolecuc mutant displayed the same 'bald' phenotype (no aerial hyphae growth) as observed for the sco mutant at low $[\mathrm{Cu}$, with development fully restored upon addition of $10 \mu \mathrm{M} \mathrm{Cu}$ (II) (Figure 9A). As previously reported, the $\mathrm{CcO}$ activity at low $[\mathrm{Cu}]$ in the sco mutant is close to the background activity measured in a cco mutant [26] (Figure 9B). The ecuc mutant on the other hand displayed higher $\mathrm{CcO}$ activity, $\sim 45 \%$ of the WT level, compared with the $20 \%$ observed for the sco mutant, and the scolecuc mutant showed similar activity levels to the single sco mutant (Figure 9B). Together these results suggest that, under low $[\mathrm{Cu}], \mathrm{Sco}^{\mathrm{Sl}}$ is a key protein in the morphological development of $S$. lividans, whereas $\mathrm{ECuC}$ has no obvious role, but does appear to have a role together with $\mathrm{Sco}^{\mathrm{Sl}}$ in $\mathrm{CcO}$ maturation.

\section{DISCUSSION}

Metallochaperones act in the cell to guide and protect a metal ion while facilitating appropriate partnerships with enzymes or proteins that require the respective metal for function. Sco proteins have received considerable attention in their role as a $\mathrm{Cu}$ metallochaperone in both eukaryotic and prokaryotic organisms. In the latter a chaperone role for Sco has been questioned, but our recent studies in S. lividans have provided strong evidence to indicate that $\mathrm{Sco}^{\mathrm{SI}}$ functions as a $\mathrm{Cu}$ metallochaperone involved in the maturation of the $\mathrm{Cu}_{\mathrm{A}}$ site in the $a a_{3}$-type $\mathrm{CcO}$ and furthermore is essential in triggering a morphological development switch [26]. These observations all occur under low $[\mathrm{Cu}]$ when it is expected that the cells most efficient chaperone and scavenging systems operate, expediting delivery and trafficking of $\mathrm{Cu}$ to meet 


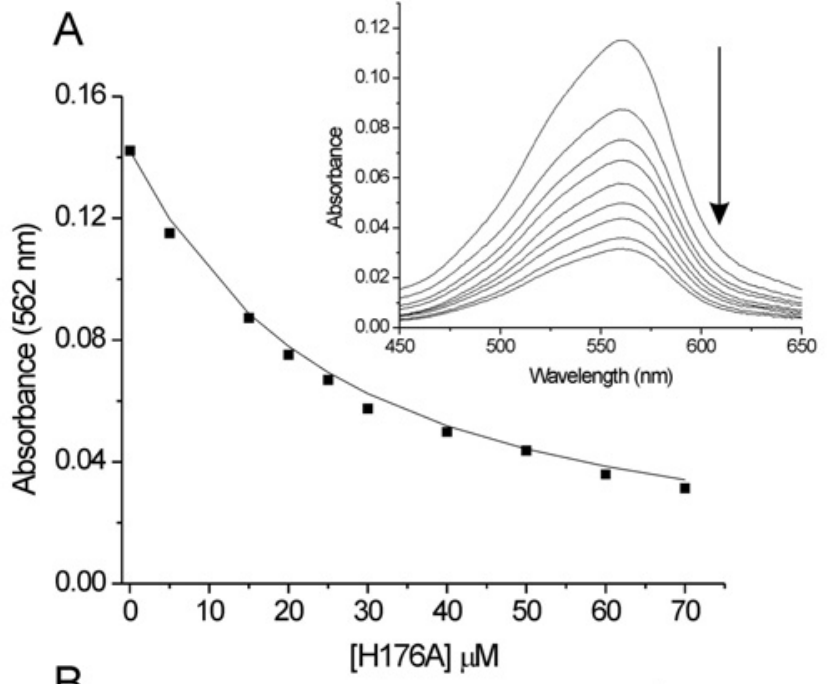

B

- WT Sco ${ }^{\mathrm{SI}}$

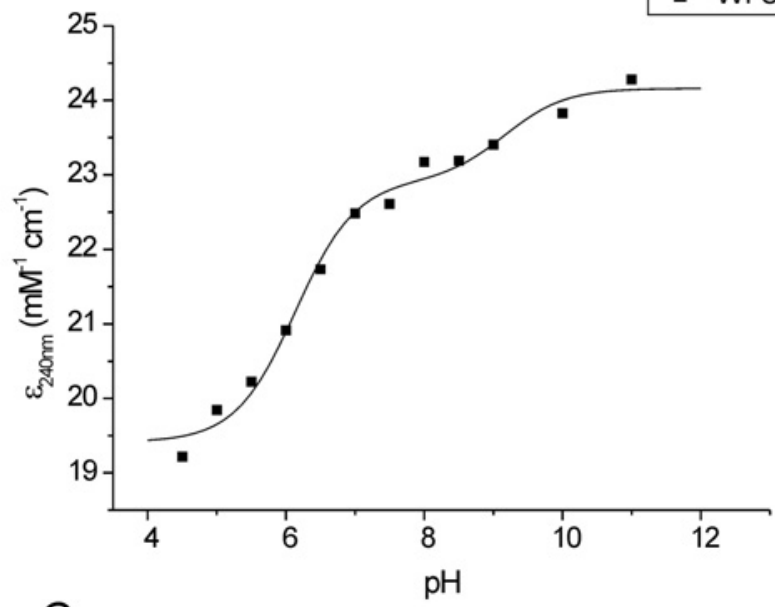

C

- $\mathrm{SCO}^{\mathrm{Si}} \mathrm{C} 86 \mathrm{~A}$

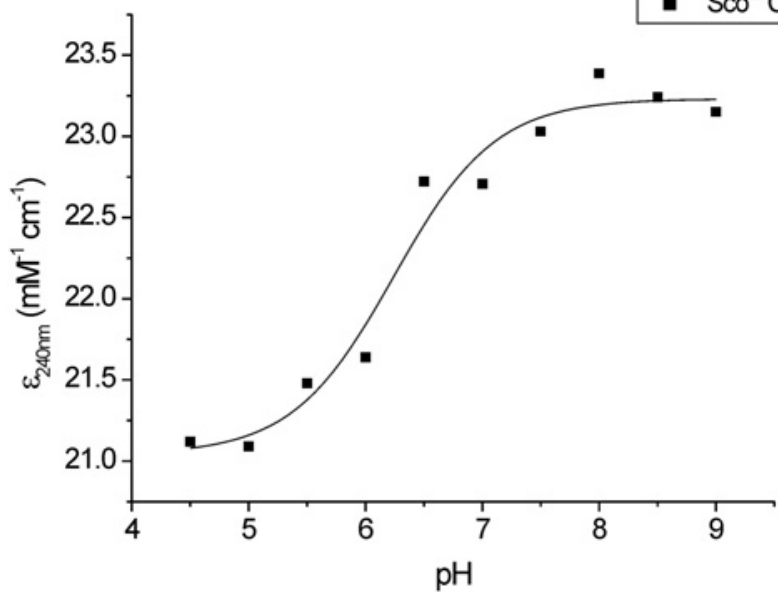

Figure 8 Determination of the $K_{d}\left(\mathrm{Cu}^{\prime}\right)$ for the $\mathrm{H} 176 \mathrm{~A}$ mutant and the $\mathrm{p} K_{\mathrm{a}}$ values of the cysteine residues in the CxxxC Cu-binding motif of $\mathrm{Sco}^{\mathrm{SI}}$

(A) The $K_{d}\left(\mathrm{Cu}^{\prime}\right)$ for the $\mathrm{H} 176 \mathrm{~A}$ mutant was determined using $\left[\mathrm{Cu}^{\prime}(\mathrm{BCA})_{2}\right]^{3-}$ as a competitive probe under $\mathrm{Cu}(\mathrm{I})$-limiting conditions. Inset: the absorbance at $562 \mathrm{~nm}$ in the visible spectrum of $\left[\mathrm{Cu}^{\prime}(\mathrm{BCA})_{2}\right]^{3-}$ decreases upon addition of the $\mathrm{H} 176 \mathrm{~A} \mathrm{Sc0}{ }^{\mathrm{Sl}}$ variant with a plot of this absorbance change against $[\mathrm{H} 176 \mathrm{~A}]$ to determine the $K_{d}\left(\mathrm{Cu}^{\prime}\right)$ using eqn (2). The line through the data points represents a best fit to the data using a $K_{d}\left(\mathrm{Cu}^{\prime}\right)$ of $9.0 \times 10^{-15} \mathrm{M}$. Conditions used: $0-50 \mu \mathrm{M}[\mathrm{H} 176 \mathrm{~A}], 30 \mu \mathrm{M}\left[\mathrm{Cu}^{\prime}\right]_{\text {total }}$ and $120 \mu \mathrm{M}$ [BCA]. (B and C) Change in absorbance at $240 \mathrm{~nm}$ as a function of $\mathrm{pH}$ for WT $(30 \mu \mathrm{M})$ and the C86A mutant $(30 \mu \mathrm{M})$ of $\mathrm{Sco}^{\mathrm{Sl}}$. For WT the data points are fitted to two ionizations (eqn 4) and for the C86A mutant a single ionization process (eqn 3 ).
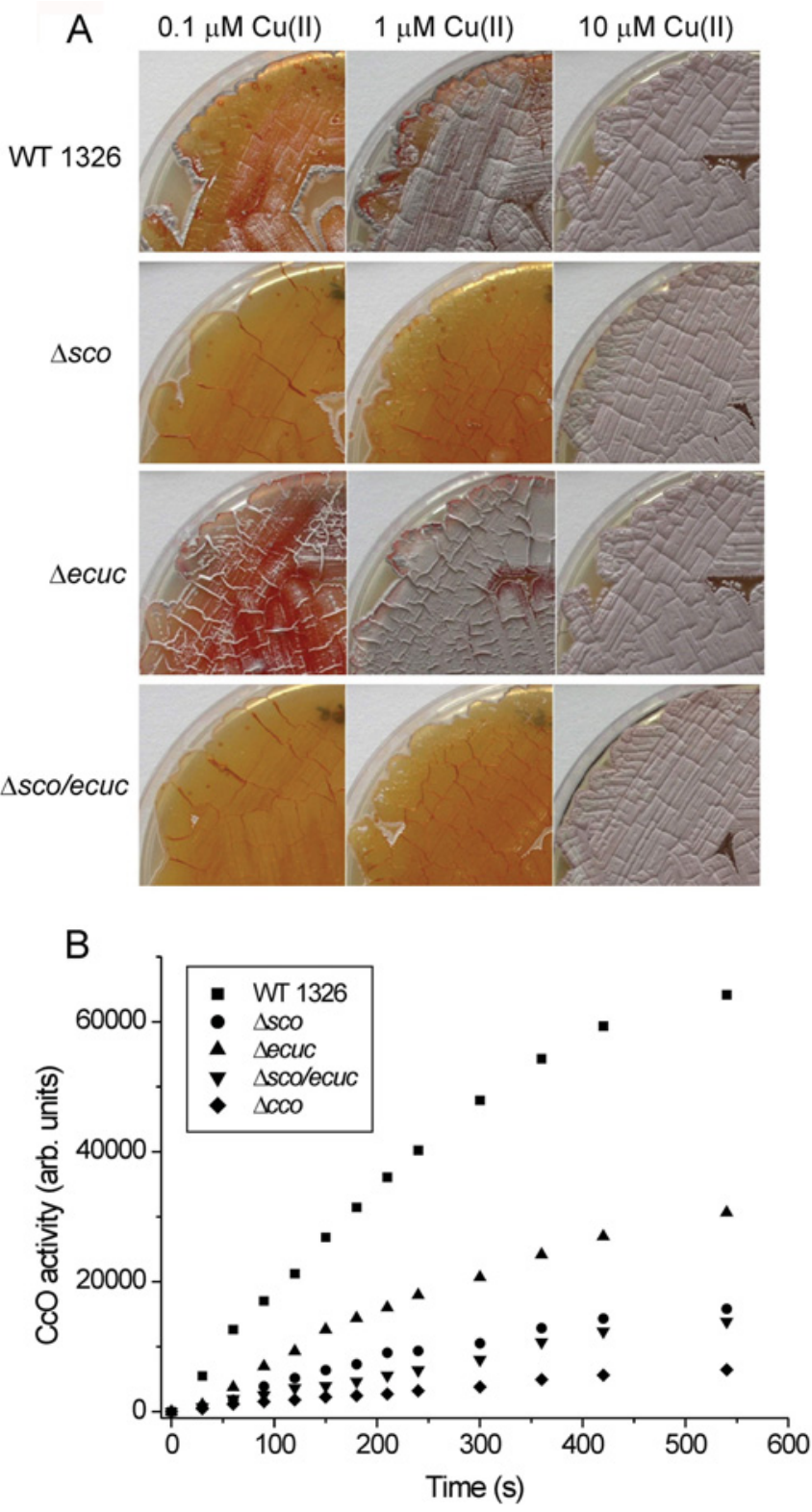

Figure 9 Morphology and Cc0 activity in S. lividans 1326 (WT), $\Delta s c 0$ $\Delta e c u c$ and the $\Delta$ sco/ecuc mutant

(A) WT and mutants were grown on R5 medium supplemented with $0.1,1$ and $10 \mu \mathrm{M} \mathrm{Cu(II)} \mathrm{for}$ 5 days. (B) In vivo detection of $\mathrm{CcO}$ activity with TMPD as substrate as described in [26] and in the Materials and methods section (S.D. varied from $5 \%$ to $16 \%$ ).

the metabolic needs of the cell. $\mathrm{Sco}^{\mathrm{Sl}}$ is secreted in S. livdians via the Sec pathway so it is likely to acquire $\mathrm{Cu}$ once folded in the extracytoplasmic environment. One possibility for $\mathrm{Cu}$ acquisition by $\mathrm{Sco}^{\mathrm{Sl}}$ is via another chaperone, such as ECuC. The structure of $\mathrm{Cu}(\mathrm{I})-\mathrm{ECuC}$ reveals a $\mathrm{Cu}(\mathrm{I})$-binding site consisting of $\mathrm{Met}_{2} \mathrm{His}_{2}$ ligands in a $\mathrm{HX}_{6} \mathrm{MX}_{21} \mathrm{HXM}$ motif, which, together with the overall protein fold, reveals that $\mathrm{ECuC}$ belongs to the $\mathrm{PCu}_{\mathrm{A}} \mathrm{C}$ family of $\mathrm{Cu}$ chaperones. These proteins, which, depending on species, also bind $\mathrm{Cu}(\mathrm{I})$ in a $\mathrm{Met}_{3} \mathrm{His}$ co-ordination arrangement, are present in the more oxidizing cellular compartments of bacteria, such as the periplasm or in the case of $S$. lividans the extracytoplasmic environment, and utilize methionine ligands in place of the more oxidation-prone cysteine ligands to co-ordinate $\mathrm{Cu}(\mathrm{I}) . \mathrm{ECuC}$ is found to co-ordinate $\mathrm{Cu}(\mathrm{I})$ in a dish-shaped region with both 
methionine ligands solvent-exposed and asides co-ordinating the $\mathrm{Cu}$ ion do not participate in further protein interactions. In the absence of $\mathrm{Cu}(\mathrm{I})$ the $\mathrm{Met}_{2} \mathrm{His}_{2}$ ligands are dynamic and small changes in sheet structure in the vicinity of the $\mathrm{Cu}(\mathrm{I})$ site were observed (Figure 4). However, whether these are considerable enough to give rise to the $\mathrm{CD}$ transition between apo- and $\mathrm{Cu}(\mathrm{I})$ bound is unclear (Figure 2). It is likely that in solution apo-ECuC can access conformations with more altered sheet structure that are not detectable in the crystalline state, and that the CD spectrum may be an average representation of a number of dynamic conformations, which become stabilized on binding $\mathrm{Cu}(\mathrm{I})$. The overall charge at the $\mathrm{ECuC} \mathrm{Cu}$ site with $\mathrm{Cu}(\mathrm{I})$ bound is +1 , and this helps create a positively charged surface patch that will favour $\mathrm{Cu}$ transfer to a negatively charged recipient (Figure 7A).

According to the $\mathrm{Cu}$ trafficking hypothesis $\mathrm{Cu}$ moves from the donor chaperone to the target protein with or against a relatively shallow thermodynamic gradient as defined by $K_{\mathrm{Cu}}$, measured with purified proteins [51,52]. Using the affinity probe BCS, ECuC was determined to have subfemtomolar affinity for $\mathrm{Cu}(\mathrm{I})$. Despite inhabiting the extracytoplasmic environment, $\mathrm{Sco}^{\mathrm{Sl}}$, in contrast with ECuC, utilizes two cysteine residues and a histidine residue to co-ordinate a $\mathrm{Cu}(\mathrm{I})$ ion, with a $K_{\mathrm{d}}\left(\mathrm{Cu}^{\mathrm{I}}\right)$ $\sim 4$-fold higher than ECuC (Table 2). The very high $\mathrm{Cu}(\mathrm{I})$ affinities determined for $\mathrm{ECuC}$ and $\mathrm{Sco}^{\mathrm{Sl}}$ are in keeping with other studies on $\mathrm{Cu}$ metallochaperones, and thus trafficking between sites is proposed to involve ligand substitution-like mechanisms $[38,50,52]$. The structure of the $\mathrm{C} 90 \mathrm{~A} \mathrm{Sco}{ }^{\mathrm{Sl}}$ protein has a typical Sco-fold with a negatively charged surface patch centred around the loop harbouring the $\mathrm{Cys}^{86}$ ligand (Figure 7). Electrostatic complementarity is a hallmark of chaperone-acceptor pairs, and therefore, based on the electrostatics of $\mathrm{Sco}^{\mathrm{Sl}}$ and $\mathrm{Cu}(\mathrm{I})-\mathrm{ECuC}$ (Figure 7), a transient chaperone-acceptor complex is likely to occur. Formation of a chaperone-acceptor adduct may initiate a structural change that opens up the metal-binding site of the chaperone and enable ligand invasion by the acceptor. Therefore, coupled with a favourable thermodynamic gradient for $\mathrm{Cu}(\mathrm{I})$ transfer from $\mathrm{ECuC}$ to $\mathrm{Sco}^{\mathrm{Sl}}$, we envisage that, within the complex, $\mathrm{Sco}^{\mathrm{SI}}$ initiates a ligand-exchange mechanism enabling $\mathrm{Cu}$ to be transferred from $\mathrm{ECuC}$.

To gain further insight into the mechanism of $\mathrm{Cu}$ exchange between these two proteins alanine mutations of the $\mathrm{Cu}$ ligands in the acceptor $\mathrm{Sco}^{\mathrm{Sl}}$ were investigated. In all cases, the affinity for $\mathrm{Cu}(\mathrm{I})$ in the mutants is decreased compared with WT Sco ${ }^{\mathrm{SI}}$ (Table 2), with two of the mutants, C86A and H176A, having weaker $\mathrm{Cu}(\mathrm{I})$ affinity than $\mathrm{ECuC}$. This results in an unfavourable thermodynamic gradient for $\mathrm{Cu}(\mathrm{I})$ transfer from $\mathrm{ECuC}$ to either of these $\mathrm{Sco}^{\mathrm{Sl}}$ mutants. Despite this, $\mathrm{Cu}(\mathrm{I})$ transfer to the H176A mutant occurs and factors other than the $\mathrm{Cu}(\mathrm{I})$ affinity of $\mathrm{Sco}^{\mathrm{SI}}$ must play a role. One of these may be the ability to tune the ionization properties of the cysteine residues in the $\mathrm{CxxxC} \mathrm{Cu}$ binding motif of $\mathrm{Sco}^{\mathrm{Sl}}$. The reactivity of individual cysteine residues in the Atx 1 family of metal chaperones with a CxxC motif has been shown to influence not only $\mathrm{Cu}(\mathrm{I})$ binding affinities, but also the reaction rates of $\mathrm{Cu}(\mathrm{I})$ transfer, and this property is therefore deemed to be an advantage over methionine ligands in $\mathrm{Cu}(\mathrm{I})$ trafficking sites $[50,53]$. On the basis of the differences in the $\Delta \varepsilon_{240}$ values for the single cysteine mutants and the higher $\mathrm{Cu}(\mathrm{I})$ affinity for the C90A mutant compared with the C86A mutant (Table 2), we have assigned the lower (acidic) $\mathrm{p} K_{\mathrm{a}}$ in WT $\mathrm{Sco}^{\mathrm{Sl}}$ to $\mathrm{Cys}^{86}$. A higher concentration of the more reactive thiolate form of $\mathrm{Cys}^{86}$ at $\mathrm{pH} 7.5$ is also consistent with previous kinetic studies of $\mathrm{Cu}$ (II) loading to $\mathrm{Sco}^{\mathrm{Sl}}$, where we found that the $\mathrm{S}\left(\mathrm{Cys}^{86}\right)$-to- $\mathrm{Cu}(\mathrm{II})$ interaction had a higher degree of covalency than $\mathrm{Cys}^{90}$ and, importantly, $\mathrm{Cys}^{86}$ acts as the initial $\mathrm{Cu}$ (II) capture ligand in a two-step kinetic mechanism [30]. Furthermore, from the C90A $\mathrm{Sco}^{\mathrm{S1}}$ structure (Figure 5), the location of $\mathrm{Cys}^{86}$ on a loop segment rather than being locked down in helix $\alpha 1$ (as would be the case for $\mathrm{Cys}^{90}$ ) is favourable for conformational sampling by the $\mathrm{Cys}^{86}$ side chain within the transient complex. Therefore we propose, in trafficking $\mathrm{Cu}(\mathrm{I})$ from $\mathrm{ECuC}$ to $\mathrm{Sco}^{\mathrm{Sl}}$, that a transient electrostatic complex is formed, in which $\mathrm{Cys}^{86}$ carries out the initial nucleophilic attack (ligand substitution) on the $\mathrm{Cu}(\mathrm{I})$ ion bound in the $\mathrm{ECuC}$ site, with subsequent ligand exchange occurring to form the $\mathrm{Sco}^{\mathrm{Sl}} \mathrm{Cu}(\mathrm{I})$-binding site, without dissociation of bound $\mathrm{Cu}(\mathrm{I})$ into the solvent.

$\mathrm{Sco}^{\mathrm{Sl}}$ has previously been shown to be essential for morphological development [26]. Therefore a role for ECuC in morphological development would be expected based on the in vitro data revealing $\mathrm{ECuC}$ as a $\mathrm{Cu}(\mathrm{I})$ donor for $\mathrm{Sco}^{\mathrm{Sl}}$. However, morphological development in the $\Delta e c u c$ mutant is similar to that of the WT (Figure 9A), whereas the $\mathrm{CcO}$ activity in the mutant is significantly reduced ( $45 \%$ of WT activity, Figure 9B). This underscores that morphological development does not depend on the level of $\mathrm{CcO}$ activity [26] and furthermore demonstrates the involvement of $\mathrm{ECuC}$ together with $\mathrm{Sco}^{\mathrm{Sl}}$ in $\mathrm{CcO}$ maturation. A model for extracytoplasmic $\mathrm{Cu}$ trafficking in $\mathrm{S}$. lividans may include a direct functional link between $\mathrm{ECuC}$ and a putative $\mathrm{Cu}$ transporter encoded by SLI4212, adjacent to ECuC (SLI4213). It has been suggested that cuproproteins and chaperones may be cofactored following the re-routing of extracytoplasmic/periplasmic $\mathrm{Cu}$ via the cytosol and redelivered as $\mathrm{Cu}(\mathrm{I})$ by $\mathrm{P}_{1}$-type ATPases [54]. As $\mathrm{Cu}(\mathrm{II})-\mathrm{ECuC}$ could not be detected in vitro, we infer that efficient $\mathrm{Cu}(\mathrm{I})$ loading of $\mathrm{ECuC}$ at low $[\mathrm{Cu}]$ in vivo may depend on the SLI4212 transporter and an imbalance in (temporal) expression or localization of the two proteins may therefore hamper the efficiency of $\mathrm{CcO}$ maturation (Figure 9B).

We have previously demonstrated the requirement for $\mathrm{Cu}(\mathrm{II})-$ $\mathrm{Sco}^{\mathrm{Sl}}$ and not $\mathrm{Cu}(\mathrm{I})-\mathrm{Sco}^{\mathrm{Sl}}$ to rescue $\mathrm{CcO}$ activity in the $\Delta$ sco mutant [26]. One could envisage that $\mathrm{Sco}^{\mathrm{Sl}}$ to some extent could scavenge $\mathrm{Cu}$ (II) directly from extracytoplasmic pools at low [Cu] without the need for another chaperone, whereas complete and efficient loading requires $\mathrm{ECuC}$ as a $\mathrm{Cu}(\mathrm{I})$ donor and then the subsequent requirement of an oxidizing molecule or protein. This scenario fits with the observation that for morphological development to take place $\mathrm{ECuC}$ is not required, suggesting that delivery of $\mathrm{Cu}$ to another $\mathrm{Sco}^{\mathrm{Sl}}$ target, which we predicted previously to be a cuproenzyme involved in the initiation of aerial hyphae [26], does not depend on $\mathrm{ECuC}$ as a $\mathrm{Cu}(\mathrm{I})$ donor. Thus in $S$. lividans extracytoplasmic $\mathrm{Cu}$ trafficking appears to be a branched pathway, where one branch requires both $\mathrm{Sco}^{\mathrm{Sl}}$ and $\mathrm{ECuC}$ to participate in cofactoring the $\mathrm{Cu}_{\mathrm{A}}$ domain of $\mathrm{CcO}$, whereas the other branch, which awaits full characterization, uses only $\mathrm{Sco}^{\mathrm{SI}}$ to deliver $\mathrm{Cu}$ and initiate development.

\section{AUTHOR CONTRIBUTION}

Jonathan Worrall and Erik Vijgenboom conceived and designed the project. Katie Blundell, Michael Hough and Erik Vijgenboom carried out experimental work. All authors analysed and interpreted the data, and contributed to the writing of the paper.

\section{ACKNOWLEDGEMENT}

We thank the Diamond Light Source for access to beamlines 102, 103and 124 (East of England Macromolecular Crystallography BAG, MX7461).

\section{FUNDING}

K.L.I.M.B. is funded by a Ph.D. studentship from the University of Essex. 


\section{REFERENCES}

1 Macomber, L. and Imlay, J. A. (2009) The iron-sulfur clusters of dehydratases are primary intracellular targets of copper toxicity. Proc. Natl. Acad. Sci. U.S.A. 106, 8344-8349

2 Pufahl, R. A., Singer, C. P., Peariso, K. L., Lin, S. J., Schmidt, P. J., Fahrni, C. J., Culotta, V. C., Penner-Hahn, J. E. and O'Halloran, T. V. (1997) Metal ion chaperone function of the soluble $\mathrm{Cu}(\mathrm{I})$ receptor Atx1. Science 278, 853-856

3 O'Halloran, T. V. and Culotta, V. C. (2000) Metallochaperones, an intracellular shuttle service for metal ions. J. Biol. Chem. 275, 25057-25060

4 Robinson, N. J. and Winge, D. R. (2010) Copper metallochaperones. Annu. Rev. Biochem. 79, 537-562

5 Arnesano, F., Banci, L., Bertini, I., Cantini, F., Ciofi-Baffoni, S., Huffman, D. L. and O'Halloran, T. V. (2001) Characterization of the binding interface between the copper chaperone Atx1 and the first cytosolic domain of Ccc2 ATPase. J. Biol. Chem. 276, 41365-41376

6 Banci, L., Bertini, I., Cantini, F., Chasapis, C. T., Hadjiliadis, N. and Rosato, A. (2005) A NMR study of the interaction of a three-domain construct of ATP7A with copper $(I)$ and copper(I)-HAH1: the interplay of domains. J. Biol. Chem. 280, 38259-38263

7 Banci, L., Bertini, I., Cantini, F., Felli, I. C., Gonnelli, L., Hadjiliadis, N., Pierattelli, R., Rosato, A. and Voulgaris, P. (2006) The Atx1-Ccc2 complex is a metal-mediated protein-protein interaction. Nat. Chem. Biol. 2, 367-368

8 Banci, L., Bertini, I., Ciofi-Baffoni, S., Kandias, N. G., Robinson, N. J., Spyroulias, G. A., Su, X. C., Tottey, S. and Vanarotti, M. (2006) The delivery of copper for thylakoid import observed by NMR. Proc. Natl. Acad. Sci. U.S.A. 103, 8320-8325

9 Abriata, L. A., Banci, L., Bertini, I., Ciofi-Baffoni, S., Gkazonis, P., Spyroulias, G. A., Vila A. J. and Wang, S. (2008) Mechanism of Cu(A) assembly. Nat. Chem. Biol. 4, 599-601

10 Tsukihara, T., Aoyama, H., Yamashita, E., Tomizaki, T., Yamaguchi, H., Shinzawa-Itoh, K., Nakashima, R., Yaono, R. and Yoshikawa, S. (1996) The whole structure of the 13-subunit oxidized cytochrome c oxidase at $2.8 \AA$. Science $272,1136-1144$

11 Horng, Y. C., Cobine, P. A., Maxfield, A. B., Carr, H. S. and Winge, D. R. (2004) Specific copper transfer from the Cox17 metallochaperone to both Sco1 and Cox11 in the assembly of yeast cytochrome c oxidase. J. Biol. Chem. 279, 35334-35340

12 Tzagoloff, A., Capitanio, N., Nobrega, M. P. and Gatti, D. (1990) Cytochrome oxidase assembly in yeast requires the product of COX11, a homolog of the $P$. denitrificans protein encoded by ORF3. EMBO J. 9, 2759-2764

13 Hiser, L., Di Valentin, M., Hamer, A. G. and Hosler, J. P. (2000) Cox11p is required for stable formation of the $\mathrm{Cu}(\mathrm{B})$ and magnesium centers of cytochrome $\mathrm{C}$ oxidase. J. Biol. Chem. 275, 619-623

14 Glerum, D. M., Shtanko, A. and Tzagoloff, A. (1996) SC01 and SC02 act as high copy suppressors of a mitochondrial copper recruitment defect in Saccharomyces cerevisiae. J. Biol. Chem. 271, 20531-20535

15 Rentzsch, A., Krummeck-Weiss, G., Hofer, A., Bartuschka, A., Ostermann, K. and Rodel, G. (1999) Mitochondrial copper metabolism in yeast: mutational analysis of Sco1p involved in the biogenesis of cytochrome c oxidase. Curr. Genet. 35, 103-108

16 Nittis, T., George, G. N. and Winge, D. R. (2001) Yeast Sc01, a protein essential for cytochrome c oxidase function is a $\mathrm{Cu}(\mathrm{I})$-binding protein. J. Biol. Chem. 276 , 42520-42526

17 Banci, L., Bertini, I., Cavallaro, G. and Ciofi-Baffoni, S. (2011) Seeking the determinants of the elusive functions of Sco proteins. FEBS J. 278, 2244-2262

18 Banci, L., Bertini, I., Ciofi-Baffoni, S., Katsari, E., Katsaros, N., Kubicek, K. and Mangani, S. (2005) A copper(I) protein possibly involved in the assembly of CuA center of bacterial cytochrome c oxidase. Proc. Natl. Acad. Sci. U.S.A. 102, 3994-3999

19 Serventi, F., Youard, Z. A., Murset, V., Huwiler, S., Buhler, D., Richter, M., Luchsinger, R., Fischer, H. M., Brogioli, R., Niederer, M. and Hennecke, H. (2012) Copper starvation-inducible protein for cytochrome oxidase biogenesis in Bradyrhizobium japonicum. J. Biol. Chem. 287, 38812-38823

20 Thompson, A. K., Gray, J., Liu, A. and Hosler, J. P. (2012) The roles of Rhodobacter sphaeroides copper chaperones PCu(A)C and Sco (PrrC) in the assembly of the copper centers of the $\mathrm{aa}_{3}$-type and the $\mathrm{cbb}_{3}$-type cytochrome $\mathrm{c}$ oxidases. Biochim. Biophys. Acta 1817, 955-964

21 Cruz-Morales, P., Vijgenboom, E., Iruegas-Bocardo, F., Girard, G., Yanez-Guerra, L. A., Ramos-Aboites, H. E., Pernodet, J. L., Anne, J., van Wezel, G. P. and Barona-Gomez, F. (2013) The genome sequence of Streptomyces lividans 66 reveals a novel tRNA-dependent peptide biosynthetic system within a metal-related genomic island Genome Biol. Evol. 5, 1165-1175

22 Kieser, T. and Hopwood, D. A. (1991) Genetic manipulation of Streptomyces: integrating vectors and gene replacement. Methods Enzymol. 204, 430-458

23 Ueda, K., Tomaru, Y., Endoh, K. and Beppu, T. (1997) Stimulatory effect of copper on antibiotic production and morphological differentiation in Streptomyces tanashiensis. J. Antibiot. (Tokyo) 50, 693-695

24 Keijser, B. J., van Wezel, G. P., Canters, G. W., Kieser, T. and Vijgenboom, E. (2000) The ram-dependence of Streptomyces lividans differentiation is bypassed by copper. J. Mol. Microbiol. Biotechnol. 2, 565-574
25 Fujimoto, M., Yamada, A., Kurosawa, J., Kawata, A., Beppu, T., Takano, H. and Ueda, K. (2012) Pleiotropic role of the Sc01/SenC family copper chaperone in the physiology of Streptomyces. Microbiol. Biotechnol. 5, 477-488

26 Blundell, K. L. I. M., Wilson, M. T., Svistunenko, D. A., Vijgenboom, E. and Worrall, J. A. R. (2013) Morphological development and cytochrome c oxidase activity in Streptomyces lividans are dependent on the action of a copper bound Sco protein. Open Biol. 3, 120163

27 Worrall, J. A. R. and Vijgenboom, E. (2010) Copper mining in Streptomyces: enzymes, natural products and development. Nat. Prod. Rep. 27, 742-756

28 Mattatall, N. R., Jazairi, J. and Hill, B. C. (2000) Characterization of YpmQ, an accessory protein required for the expression of cytochrome c oxidase in Bacillus subtilis. J. Biol. Chem. 275, 28802-28809

29 Siluvai, G. S., Nakano, M., Mayfield, M. and Blackburn, N. J. (2011) The essential role of the $\mathrm{Cu}(\mathrm{II})$ state of $\mathrm{Sco}$ in the maturation of the $\mathrm{Cu}(\mathrm{A})$ center of cytochrome oxidase: evidence from H135Met and H135SeM variants of the Bacillus subtilis Sco. J. Biol. Inorg Chem. 16, 285-297

30 Blundell, K. L. I. M., Wilson, M. T., Vijgenboom, E. and Worrall, J. A. R. (2013) The role of the Cys-X-X-X-Cys motif on the kinetics of cupric ion loading to the Streptomyces lividans Sco protein. Dalton Trans. 42, 10608-10616

31 Kieser, T. B., Bibb, M. J., Buttner, M. J., Chater, K. F. and Hopwood, D. A. (2000) Practical Streptomyces Genetics, John Innes Foundation, Norwich, U.K.

32 Green, G. N. and Gennis, R. B. (1983) Isolation and characterization of an Escherichia coli mutant lacking cytochrome $d$ terminal oxidase. J. Bacteriol. 154, 1269-1275

33 Mueller, J. P. and Taber, H. W. (1989) Isolation and sequence of ctaA, a gene required for cytochrome aa3 biosynthesis and sporulation in Bacillus subtilis. J. Bacteriol. 171 4967-4978

34 Gasteiger, E., Gattiker, A., Hoogland, C., Ivanyi, I., Appel, R. D. and Bairoch, A. (2003) ExPASy: the proteomics server for in-depth protein knowledge and analysis. Nucleic Acids Res. 31, 3784-3788

35 Whitmore, L. and Wallace, B. A. (2004) DICHROWEB, an online server for protein secondary structure analyses from circular dichroism spectroscopic data. Nucleic Acids Res. 32, W668-W673

36 Xiao, Z., Donnelly, P. S., Zimmermann, M. and Wedd, A. G. (2008) Transfer of copper between bis(thiosemicarbazone) ligands and intracellular copper-binding proteins. Insights into mechanisms of copper uptake and hypoxia selectivity. Inorg. Chem. $\mathbf{4 7}$ 4338-4347

37 Xiao, Z., Loughlin, F., George, G. N., Howlett, G. J. and Wedd, A. G. (2004) C-terminal domain of the membrane copper transporter Ctr1 from Saccharomyces cerevisiae binds four $\mathrm{Cu}(\mathrm{I})$ ions as a cuprous-thiolate polynuclear cluster: sub-femtomolar $\mathrm{Cu}(\mathrm{I})$ affinity of three proteins involved in copper trafficking. J. Am. Chem. Soc. 126, 3081-3090

38 Xiao, Z., Brose, J., Schimo, S., Ackland, S. M., La Fontaine, S. and Wedd, A. G. (2011) Unification of the copper(I) binding affinities of the metallo-chaperones Atx1, Atox1, and related proteins: detection probes and affinity standards. J. Biol. Chem. 286, 11047-11055

39 Battye, T. G., Kontogiannis, L., Johnson, 0., Powell, H. R. and Leslie, A. G. (2011) iMOSFLM: a new graphical interface for diffraction-image processing with MOSFLM. Acta Crystallogr. D Biol. Crystallogr. 67, 271-281

40 Evans, P. (2006) Scaling and assessment of data quality. Acta Crystallogr. D Biol. Crystallogr. 62, 72-82

41 Adams, P. D., Afonine, P. V., Bunkoczi, G., Chen, V. B., Davis, I. W., Echols, N., Headd, J. J., Hung, L. W., Kapral, G. J., Grosse-Kunstleve, R. W et al. (2010) PHENIX: a comprehensive Python-based system for macromolecular structure solution. Acta Crystallogr. D Biol. Crystallogr. 66, 213-221

42 Cowtan, K. (2006) The Buccaneer software for automated model building. 1. Tracing protein chains. Acta Crystallogr. D Biol. Crystallogr. 62, 1002-1011

43 Perrakis, A., Morris, R. and Lamzin, V. S. (1999) Automated protein model building combined with iterative structure refinement. Nat. Struct. Biol. 6, 458-463

44 Murshudov, G. N., Vagin, A. A. and Dodson, E. J. (1997) Refinement of macromolecular structures by the maximum-likelihood method. Acta Crystallogr. D Biol. Crystallogr. 53, 240-255

45 Emsley, P. and Cowtan, K. (2004) Coot: model-building tools for molecular graphics. Acta Crystallogr. D Biol. Crystallogr. 60, 2126-2132

46 Davis, I. W., Leaver-Fay, A., Chen, V. B., Block, J. N., Kapral, G. J., Wang, X., Murray, L. W., Arendall, 3rd, W. B., Snoeyink, J., Richardson, J. S. and Richardson, D. C. (2007) MolProbity: all-atom contacts and structure validation for proteins and nucleic acids. Nucleic Acids Res. 35, W375-W383

47 Long, F., Vagin, A. A., Young, P. and Murshudov, G. N. (2008) BALBES: a molecular-replacement pipeline. Acta Crystallogr. D Biol. Crystallogr. 64, 125-132

48 Sreerama, N. and Woody, R. W. (2003) Structural composition of betal- and betall-proteins. Protein Sci. 12, 384-388 
49 Ledwidge, R., Hong, B., Dotsch, V. and Miller, S. M. (2010) NmerA of Tn501 mercuric ion reductase: structural modulation of the pKa values of the metal binding cysteine thiols. Biochemistry 49, 8988-8998

50 Badarau, A. and Dennison, C. (2011) Copper trafficking mechanism of CXXC-containing domains: insight from the pH-dependence of their $\mathrm{Cu}(\mathrm{I})$ affinities. J. Am. Chem. Soc. 133, 2983-2988

51 Banci, L., Bertini, I., Ciofi-Baffoni, S., Kozyreva, T., Zovo, K. and Palumaa, P. (2010) Affinity gradients drive copper to cellular destinations. Nature $\mathbf{4 6 5}$, $645-648$

Received 2 January 2014/14 February 2014; accepted 19 February 2014

Published as BJ Immediate Publication 19 February 2014, doi:10.1042/BJ20140017
52 Badarau, A. and Dennison, C. (2011) Thermodynamics of copper and zinc distribution in the cyanobacterium Synechocystis PCC 6803. Proc. Natl. Acad. Sci. U.S.A. 108 13007-13012

53 Rodriguez-Granillo, A., Crespo, A., Estrin, D. A. and Wittung-Stafshede, P. (2010) Copper-transfer mechanism from the human chaperone Atox1 to a metal-binding domain of Wilson disease protein. J. Phys. Chem. B. 114, 3698-3706

54 Waldron, K. J., Firbank, S. J., Dainty, S. J., Perez-Rama, M., Tottey, S. and Robinson, N. J. (2010) Structure and metal loading of a soluble periplasm cuproprotein. J. Biol. Chem. 285, 32504-32511 


\section{SUPPLEMENTARY ONLINE DATA}

\section{Structural and mechanistic insights into an extracytoplasmic copper trafficking pathway in Streptomyces lividans}

Katie L. I. M. BLUNDELL*, Michael A. HOUGH*, Erik VIJGENBOOM† and Jonathan A. R. WORRALL*1

${ }^{*}$ School of Biological Sciences, University of Essex, Wivenhoe Park, Colchester CO4 3SQ, U.K.

$†$ † Molecular Biotechnology, Institute of Biology, Sylvius Laboratory, Leiden University, PO Box 9505, 2300RA Leiden, The Netherlands

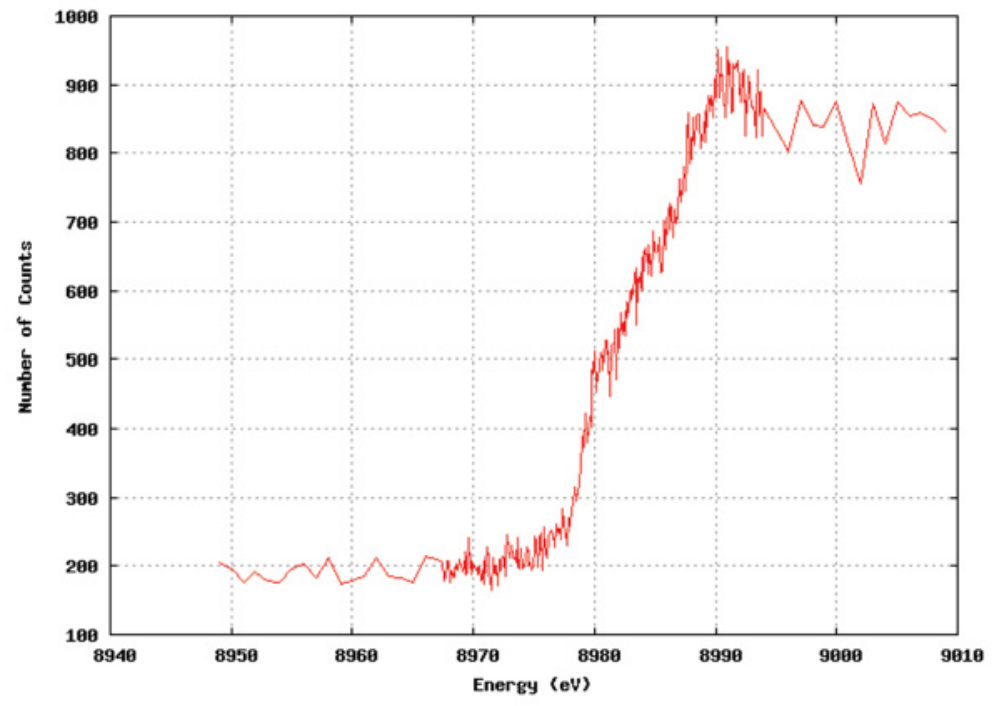

Figure S1 X-ray fluorescence scan at the Cu edge for a single crystal of $S$. lividans $\mathrm{Cu}(\mathrm{I})$-ECuC

\footnotetext{
1 To whom correspondence should be addressed (email jworrall@essex.ac.uk).
} 
A

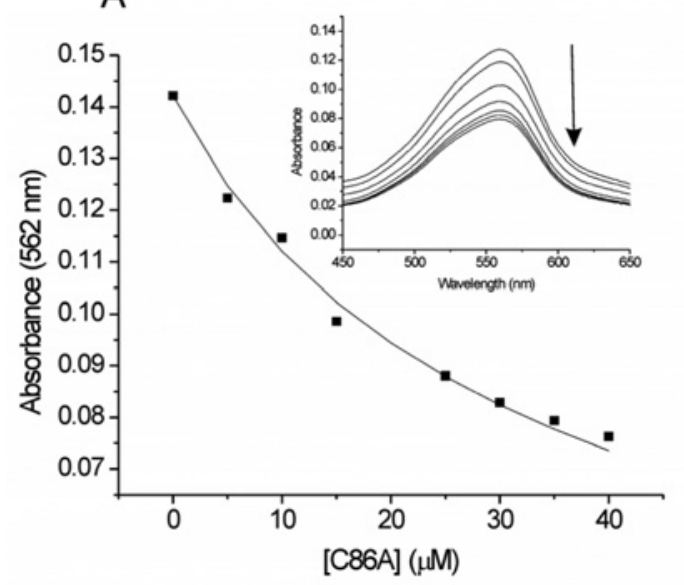

B

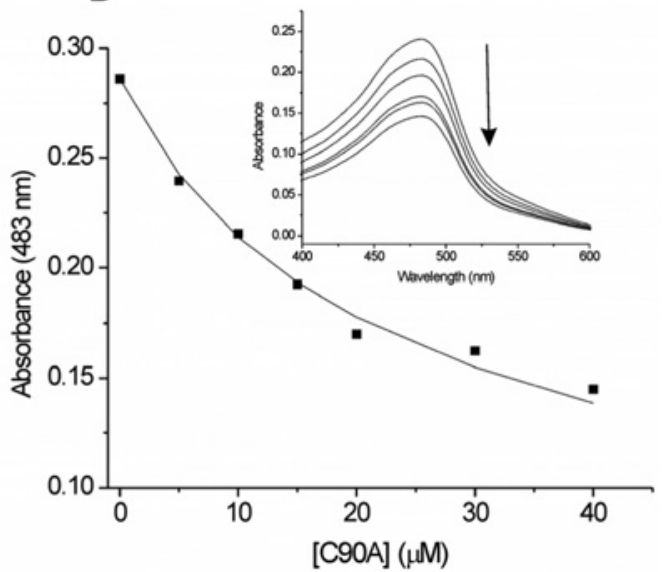

\section{Figure S2 Determination of the $K_{\mathrm{d}}\left(\mathrm{Cu}^{\prime}\right)$ for the $\mathrm{C86A}$ and $\mathrm{C90A}$ mutants of $\mathrm{Sc}^{\mathrm{SI}}$}

(A) The $K_{d}\left(\mathrm{Cu}^{\prime}\right)$ for the $\mathrm{C} 86 \mathrm{~A}$ mutant was determined using $\left[\mathrm{Cu}(\mathrm{BCA})_{2}\right]^{3-}$ as a competitive probe under $\mathrm{Cu}(\mathrm{I})$-limiting conditions. Inset: the absorbance at $562 \mathrm{~nm}$ in the visible spectrum of $\left[\mathrm{Cu}^{\prime}(\mathrm{BCA})_{2}\right]^{3-}$ decreases upon the addition of the $\mathrm{C} 86 \mathrm{~A} \mathrm{Sc0}{ }^{\mathrm{Sl}}$ mutant with a plot of this absorbance change against [C86A] to determine the $K_{\mathrm{d}}(\mathrm{Cu}$ ) using eqn (2) of the main text. The line through the data points represents a best fit to the data using a $K_{d}\left(\mathrm{Cu}^{\prime}\right)$ of $7.3 \times 10^{-14} \mathrm{M}$. Conditions used: $0-40 \mu \mathrm{M}[\mathrm{C} 86 \mathrm{~A}], 18 \mu \mathrm{M}$ [Cu'] $]_{\text {total }}$ and $75 \mu \mathrm{M}\left[\mathrm{BCA}\right.$ ]. (B) The $K_{d}\left(\mathrm{Cu} \mathbf{U}^{\prime}\right)$ for the C90A mutant was determined using $\left[\mathrm{Cu}^{\prime}(\mathrm{BCS})_{2}\right]^{3-}$ as a competitive probe under $\mathrm{Cu}(\mathrm{l})$-limiting conditions. Inset: the absorbance at $483 \mathrm{~nm}$ in the visible spectrum of $\left[\mathrm{Cu}(\mathrm{BCS})_{2}\right]^{3-}$ decreases upon the addition of the $\mathrm{C} 90 \mathrm{~A} \mathrm{Sc0}{ }^{\mathrm{SI}}$ mutant with a plot of this absorbance change against [C90A] to determine the $K_{\mathrm{d}}\left(\mathrm{Cu}^{\prime}\right)$ using eqn (2) of the main text. The line through the data points represents a best fit to the data using a $K_{d}\left(\mathrm{Cu}^{\prime}\right)$ of $2.9 \times 10^{-16} \mathrm{M}$. Conditions used: 0-40 $\mu \mathrm{M}[\mathrm{C} 90 \mathrm{~A}], 22 \mu \mathrm{M}$ [Cu'] total and $60 \mu \mathrm{M}[\mathrm{BCS}]$.
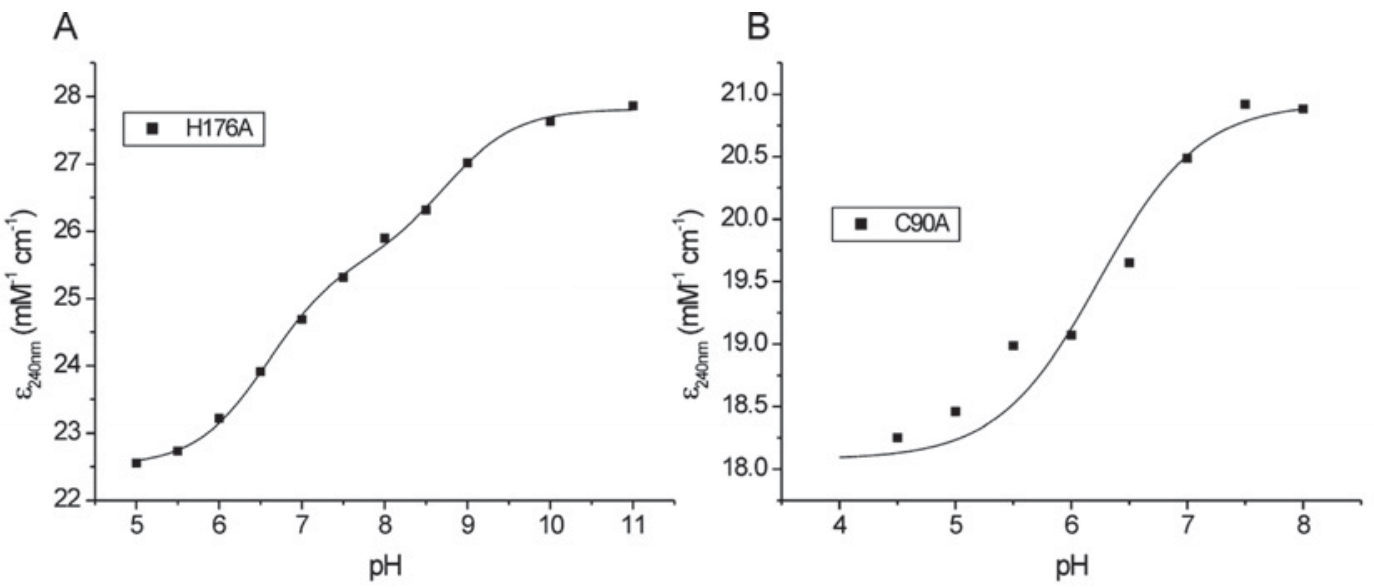

Figure S3 Determination of the $\mathrm{p} K_{\mathrm{a}}$ values of the cysteine residues in the H176A (A) and C90A (B) mutants of Sco ${ }^{\text {Sl }}$

Changes in absorbance at $240 \mathrm{~nm}$ are plotted as a function of $\mathrm{pH}$ for the $\mathrm{H} 176 \mathrm{~A}(30 \mu \mathrm{M})$ and the $\mathrm{C} 90 \mathrm{~A}(30 \mu \mathrm{M})$ mutants of Sco ${ }^{\mathrm{Sl}}$. For H176A the data points are fitted to two ionizations (eqn 4$)$ and for the C90A mutant a single ionization process (eqn 3).

Received 2 January 2014/14 February 2014; accepted 19 February 2014

Published as BJ Immediate Publication 19 February 2014, doi:10.1042/BJ20140017 